\title{
Specific and Global RNA Regulators in Pseudomonas aeruginosa
}

\author{
Petra Pusic $\mathbb{C}^{\mathbb{B}}$, Elisabeth Sonnleitner and Udo Bläsi *
}

check for

updates

Citation: Pusic, P.; Sonnleitner, E.; Bläsi, U. Specific and Global RNA Regulators in Pseudomonas aeruginosa. Int. J. Mol. Sci. 2021, 22, 8632. https://doi.org/10.3390/ijms22168632

Academic Editor: Alicja Wegrzyn

Received: 19 July 2021

Accepted: 8 August 2021

Published: 11 August 2021

Publisher's Note: MDPI stays neutral with regard to jurisdictional claims in published maps and institutional affiliations.

Copyright: (C) 2021 by the authors. Licensee MDPI, Basel, Switzerland. This article is an open access article distributed under the terms and conditions of the Creative Commons Attribution (CC BY) license (https:/ / creativecommons.org/licenses/by/ $4.0 /)$.

\author{
Max Perutz Labs, Department of Microbiology, Immunobiology and Genetics, Centre of Molecular Biology, \\ Vienna Biocenter (VBC), University of Vienna, Dr. Bohrgasse 9/4, 1030 Vienna, Austria; \\ petra.pusic@univie.ac.at (P.P.); elisabeth.sonnleitner@univie.ac.at (E.S.) \\ * Correspondence: udo.blaesi@univie.ac.at
}

\begin{abstract}
Pseudomonas aeruginosa (Pae) is an opportunistic pathogen showing a high intrinsic resistance to a wide variety of antibiotics. It causes nosocomial infections that are particularly detrimental to immunocompromised individuals and to patients suffering from cystic fibrosis. We provide a snapshot on regulatory RNAs of Pae that impact on metabolism, pathogenicity and antibiotic susceptibility. Different experimental approaches such as in silico predictions, co-purification with the RNA chaperone Hfq as well as high-throughput RNA sequencing identified several hundreds of regulatory RNA candidates in Pae. Notwithstanding, using in vitro and in vivo assays, the function of only a few has been revealed. Here, we focus on well-characterized small base-pairing RNAs, regulating specific target genes as well as on larger protein-binding RNAs that sequester and thereby modulate the activity of translational repressors. As the latter impact large gene networks governing metabolism, acute or chronic infections, these protein-binding RNAs in conjunction with their cognate proteins are regarded as global post-transcriptional regulators.
\end{abstract}

Keywords: Pseudomonas aeruginosa; base-pairing sRNAs; protein-binding RNAs; Hfq; Crc; RsmA; RsmN/F; post-transcriptional regulation

\section{Introduction}

High-throughput RNA sequencing (RNAseq) has revolutionized the discovery of regulatory RNAs in bacteria [1-13]. These RNA regulators are mostly non-coding and usually synthesized under certain physiological conditions [3]. Once the trigger is lost, the regulatory RNA is often co-degraded with the target mRNA [14]. Regulatory RNAs are diverse and can act at all levels of gene expression, by (i) controlling DNA maintenance and silencing [15-17], (ii) activating or repressing transcription [18-22], (iii) affecting translation and/or stability of target mRNAs [2,13,23-25], (iv) modulating the function of proteins $[18,19,21,26-29]$, or (v) by sequestering other sRNAs [30-32]. Depending on their mode of action, regulatory RNAs can be classified into seven major subgroups: small basepairing RNAs (sRNAs), dual-function (bifunctional) RNAs, protein-binding RNAs, RNA sponges, riboswitches, RNA thermometers and CRISPR RNAs. In this review, we focus on base-pairing sRNAs and protein-binding RNAs in the opportunistic human pathogen Pae.

\section{Base-Pairing RNAs in Pae}

Several different approaches were employed for the identification of sRNAs in Pae, including in silico predictions [33,34], co-purification with the RNA chaperone Hfq [35] as well as high-throughput RNAseq under different growth conditions [36-39]. A total of 573 and 233 sRNAs were detected in strain PAO1 and in the clinical isolate PA14, respectively $[37,40,41]$. Although 126 sRNAs were identified to be present in both strains, in silico predictions suggest that the actual number of common sRNA is larger [40-42]. Only a few of these RNAs have been functionally characterized. These include sRNAs involved in (i) virulence and biofilm formation (ErsA, Sr0161, Sr006, PrrF1/2, PrrH, ReaL, RgsA, Pail, NrsZ), (ii) iron metabolism (PrrF1/2 and PrrH), (iii) nitrogen metabolism (Pail 
and NrsZ), (iv) quorum sensing (PhrS, PrrF1/2 and ReaL) and (v) antibiotic susceptibility (ErsA, Sr0161 and Sr006) (Figure 1).

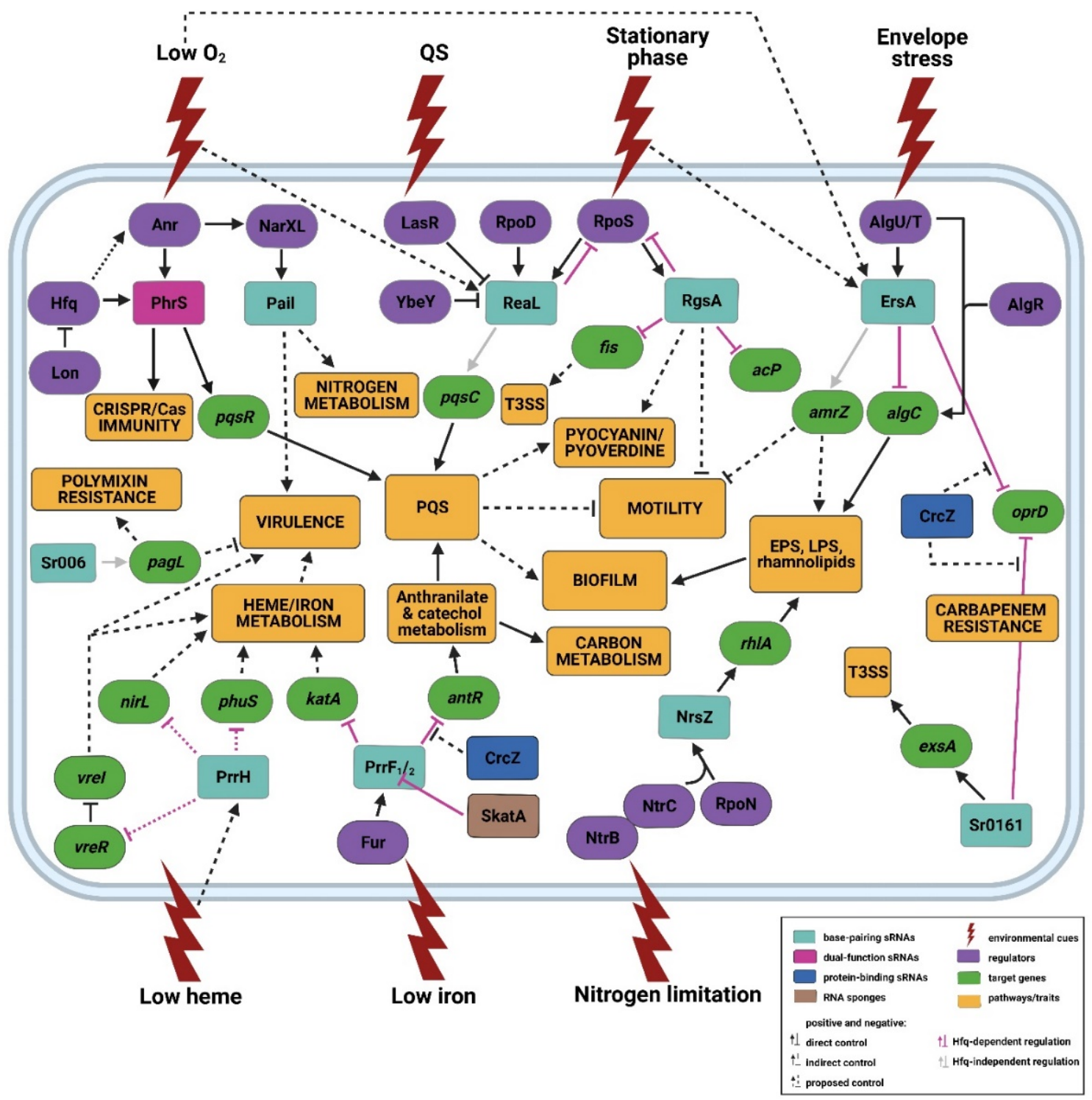

Figure 1. Regulation by base-pairing sRNAs. Characterized base-pairing RNAs (malachite green) and dual-function RNA PhrS (magenta) and their respective regulators (violet) and targets (green). The complex RNA-mediated regulatory network governs a number of metabolic and virulence-related processes (orange boxes) in response to different environmental cues (red flashes). See main text for details. $\downarrow$ : positive control; $\perp$ : negative control; dashed lines: indirect control; dotted lines: proposed control. Light grey lines indicate Hfq-independent regulation, whereas magenta lines highlight Hfq-dependent regulation.

RNA chaperones are a special class of RNA-binding proteins fostering the stability and function of sRNAs [43-46]. In Gram-negative bacteria, including Pae [47], the RNA chaperone Hfq (below for further details) can act as an RNA matchmaker, aiding in base-pairing between sRNAs and their target mRNAs, especially when the cognate sRNA/mRNA pair lacks extensive complementarity $[48,49]$.

\section{1. $\operatorname{Ers} A$}

The envelope stress-responsive sRNA $A$ (ErsA) is a trans-encoded sRNA which was initially identified in Pae strain PAO1 as a functional orthologue of Escherichia coli Spot 42 RNA [50]. ErsA was as well recognized in an RNAseq approach in Pae strain PA14 as 
SPA0122 [37]. Transcription of ers $A$ is governed by the extracytoplasmic $f$ unction (ECF) sigma factor $\mathrm{Alg} \mathrm{U} / \mathrm{T}\left(\sigma^{22}\right)$, an envelope stress response regulator [51]. The ErsA levels are elevated upon depletion of oxygen and upon entry into stationary phase [51,52]. With the aid of Hfq, ErsA represses the translation of algC mRNA (Figure 1), encoding the bifunctional enzyme phosphomannomutase/phosphoglucomutase [51]. AlgC is essential for the biosynthesis of alginate [53,54], the exopolysaccharides (EPS) Psl and Pel [55], lipopolysaccharide (LPS) [56,57] and rhamnolipids [58], which are components of the biofilm matrix during chronic infection $[59,60]$. AlgC synthesis is activated by the alginate biosynthesis regulator AlgR and the sigma factor AlgU/T [61-63], which together with the sRNA ErsA are part of an incoherent feed-forward loop, which alters the AlgC levels [51]. Apart from its role in the synthesis of biofilm matrix components, ErsA appears to contribute to biofilm development and motility by stimulating the synthesis of the transcriptional regulator AmrZ (Figure 1) [64]. Moreover, ErsA was recently reported to be involved in pathogenesis in both acute and chronic airway infections [65].

The OprD porin serves as an entry port for basic amino acids and peptides, as well as for carbapenem antibiotics [66,67]. Frameshift and nonsense mutations in the oprD gene, which prevent synthesis or result in the production of functionally impaired OprD, gave rise to diminished carbapenem susceptibility [68-74]. A recent GRILseq (Global sRNA Target Identification by Ligation and Sequencing) study revealed the oprD gene as a novel target of ErsA [52]. The sRNA ErsA negatively regulates oprD translation, which in turn leads to decreased OprD levels and thus to reduced meropenem susceptibility (Figure 1) [52].

\section{2. $\operatorname{Sr} 0161$}

The sRNA Sr0161 was discovered in Pae strain PAO1 by a GRILseq analysis [52]. The sr0161 gene is located between the genes PA0160 and opdC. Functional studies performed by Zhang et al. [53] revealed that Sr0161, like ErsA, regulates the oprD gene, and thus carbapenem susceptibility (Figure 1). In addition, Sr0161 was suggested to regulate opdP mRNA, which encodes a second porin involved in carbapenem uptake [52]. However, recent studies revealed that $o p d P$ appears not to be regulated by sRNAs [75]. At variance, opdP appeared to be translationally repressed by a regulatory complex consisting of $\mathrm{Hfq}$ and the catabolite repression protein Crc (see below). Another target of Sr0161 is the transcriptional activator of the type III secretion system (T3SS), ExsA (Figure 1) [52]. Sr0161 was shown to bind to the $5^{\prime}$ untranslated region (UTR) of exsA mRNA, and to repress its translation [52]. Hence, the sRNA Sr0161 seems to assist in several virulence-related processes.

\section{3. $\operatorname{Sr} 006$}

The sRNA Sr006 was originally annotated during a single nucleotide resolution transcriptome analysis [39]. A GRILseq approach revealed Sr006 as a positive posttranscriptional regulator of the pagL gene, encoding the lipid A 3-O deacylase (Figure 1) [52]. The acetylated form of lipid A was previously shown to be pro-inflammatory causing severe pulmonary damage in chronically infected cystic $f$ ibrosis (CF) patients [76-78]. Sr006 interacts with the 5'UTR of pagL mRNA in an Hfq-independent manner [52], resulting in an increase in the PagL levels, which in turn augment lipid A deacetylation of the LPS [76]. As a consequence, polymyxin B susceptibility is elevated $[79,80]$ and pro-inflammatory signalling is decreased [81].

\section{4. $\operatorname{PrF} 1 / 2$}

The iron-responsive sRNAs PrrF1 and PrrF2 represent functional orthologues of the E. coli sRNA RyhB [82] and Bacillus subtilis FsrA sRNA [83]. PrrF1 and PrrF2 are encoded in tandem and share $>95 \%$ sequence identity. The $p r r F$ genes are transcriptionally controlled by the $f$ erric uptake regulator Fur [33]. The PrrF RNAs have been implicated in the maintenance of iron homeostasis under iron-limiting conditions by post-transcriptionally repressing genes encoding non-essential iron-containing proteins (Figure 1) [33,52,84-87]. PrrF- 
dependent riboregulation is mediated by Hfq [47]. A GRILseq study identified an RNA sponge derived from the $3^{\prime}$ end of kat $A$ mRNA, encoding the major catalase in Pae $[52,86]$. The RNA sponge SkatA acts as a decoy for PrrF1, which interferes with PrrF1 base-pairing to the $5^{\prime}$ end of the kat $A$ transcript, and thus with translational repression $[52,86]$. Hfq was recently shown to bind to both the SkatA and PrrF RNAs, suggesting a role for their maturation and/or regulation [88].

The PrrF RNAs are further involved in the synthesis of the Pseudomonas quinolone signal (PQS), a quorum sensing (QS) quinolone affecting early biofilm development and virulence (Figure 1) [89-92]. The PrrF RNAs impact the expression of the antABC and $\angle a t B C A$ operons, encoding functions required for the catabolism of anthranilate, a precursor of PQS [85]. As a consequence, anthranilate is re-directed into the PQS anabolic pathway [85]. In addition, the PrrF sRNAs were shown to foster the synthesis of other 2akyl-4-quinolones (AQs), which are contributing to virulence [93]. The promoting effect on AQs was attributed to PrrF/Hfq-mediated repression of antR mRNA, encoding a transcriptional activator of the ant $A B C$ and cat $B C A$ operons $[47,85,94]$. Thus, the Prrf-dependent regulation of $A Q$ biosynthesis represents an example of a crosstalk between iron, carbon metabolism and virulence in Pae. In addition, a recent proteomic study further expanded the PrrF-dependent regulon for several iron-regulated proteins, which are involved in amino acid metabolism, twitching motility and zinc homeostasis [95].

\section{5. $\operatorname{PrrH}$}

The heme-responsive sRNA PrrH is transcribed from the tandem prrF1/prrF2 locus through heme-dependent anti-termination of prrF1 transcription [96]. The longer PrrH RNA binds to Hfq with lower affinity than the PrrF RNAs [97]. PrrH is deemed to finetune the expression of genes required for heme uptake and metabolism (Figure 1) [96]. For instance, nirL mRNA, which was described as a putative target of PrrH RNA [96], is part of the nirSMCFDLGHJEN operon, encoding the dissimilatory nitrite reductase NirS (cytochrome $c d_{1}$ ). The nir operon also contains genes of the heme $d_{1}$ biosynthetic pathway, which is an alternative branch of the central heme biosynthetic pathway [98]. Thus, the predicted PrrH-mediated repression of the alternative Nir heme $d_{1}$ biosynthesis under heme-limiting conditions may favor the activity of the central heme biosynthetic pathway. Moreover, PrrH is predicted to regulate phuS, the product of which is responsible for the flux of heme through the heme-oxygenase HemO [99,100]. Heme represents an abundant source of iron in the human host. Therefore, the ability of the bacterium to assimilate and utilize heme might provide a competitive advantage during infection. In silico analyses performed to reveal potential virulence targets for PrrH identified vreR as a putative candidate [99]. VreR is an anti-sigma factor of the cell surface signalling ECF sigma factor VreI, and is thought to be involved in Pae virulence [101-103]. The translational start site and coding sequence of vreR mRNA share extensive complementarity with $\operatorname{PrrH}$ [99]. Moreover, the deletion of the prrF locus leads to a threefold increase in vreR expression, suggesting a potential role of PrrF/PrrH in its regulation [99].

\subsection{ReaL}

The highly conserved sRNA ReaL (regulator of alkyl quinolone) was initially identified in strain PAO1 as PaeIII [104], and as SPA0084 in strain PA14 [37]. The ReaL levels are elevated during stationary phase, as well as under anoxic conditions. ReaL transcription is governed by the "house-keeping" sigma factor $\operatorname{RpoD}\left(\sigma^{70}\right)$ and by the stationary phase sigma factor RpoS $\left(\sigma^{38}, \sigma^{\mathrm{S}}\right)$ [105]. Moreover, ReaL impedes translation of rpoS mRNA through base-pairing, thus imposing negative feedback control (Figure 1) [106]. An additional layer of regulation in the ReaL-RpoS negative feedback loop was recently proposed. The endoribonuclease YbeY was implicated in the regulation of rpoS through degradation of ReaL [107].

ReaL is also involved in QS regulation, connecting the Las and PQS systems in Pae [105]. Las and PQS, together with the integrated quorum sensing system (IQS) and 
the Rhl QS system, represent a hierarchically organized regulatory quorum sensing network, which mediates Pae virulence during infection [108]. The PQS system is essential for shaping a more stress-tolerant bacterial population in response to harsh environmental conditions [109,110]. Moreover, PQS synthesis results in elevated biofilm formation, pyocyanin and pyoverdine synthesis [111-113], and in decreased swarming [113]. These phenotypes are commonly detected during the colonization of CF lungs [113-115]. PQS biosynthesis requires the functions encoded by the $p q s A B C D E$ and $p h n A B$ operons, as well as the $p q s H$ gene [116]. Previous reports linked LasR, the transcriptional regulator of the Las QS system, to PQS biosynthesis control [89]. Liquid chromatography coupled to mass spectrometry (LC/MS) analyses [117] demonstrated diminished levels of PQS and accumulation of its precursor 4-hydroxy-2-heptylquinoline (HHQ) in a lasR deletion strain, implicating LasR in HHQ to PQS conversion $[118,119]$. Moreover, LasR seems to directly activate $p q s H$ and $p q s R$ expression [116,120-122]. However, LasR also inhibits reaL transcription [105]. ReaL activates pqsC translation in an Hfq-independent manner, and in turn elicits elevated PQS levels and promotes establishment of PQS-dependent virulence traits (Figure 1) [105]. Therefore, LasR inhibition of reaL expression leads to diminished PQS levels and impaired PQS-related phenotypes [105]. Hence, ReaL acts as a modulator of LasR-dependent PQS biosynthesis and virulence.

\section{7. $\operatorname{Rgs} A$}

The sRNA RgsA was identified by two independent bioinformatic analyses in strain PAO1 [34,123]. Synthesis of RgsA is induced upon shift to stationary phase, and is dependent on the stationary phase sigma factor RpoS [123]. Transcription of $\operatorname{rgs} A$ is also indirectly activated by the GacA/S two-component system (TCS) [123,124]. In addition, RgsA requires Hfq for its stability [124,125]. Initial results suggested that RgsA might contribute to the oxidative stress response $[123,126]$, while another study by Lu et al. (2016) implicated RgsA in pyocyanin synthesis and swarming motility. RgsA was shown to inhibit translation of the fis and acpP mRNAs, encoding the global transcriptional regulator Fis and the acyl carrier protein AcpP, respectively, in an Hfq-dependent manner (Figure 1) [124]. Fis is a DNA-binding and bending protein $[127,128]$, which is essential for the expression of the tT3SS and T3SS-mediated cytotoxicity in Pae [129], and was recently deemed to contribute to ciprofloxacin resistance [130].

\subsection{PaiI}

The highly conserved sRNA PaiI (Pseudomonas anaerobically induced RNA I) was identified in the intergenic region between the genes PA14_13970 and PA14_13990 in strain PA14 [131]. It was shown to be abundant under anoxic conditions, and rapidly degraded upon a shift to aerobic conditions [131]. Pail transcription is induced during anaerobic denitrification, and is governed by the nitrate-responsive TCS NarL/X [131], whose expression is under control of the anaerobic regulator Anr [132]. Further studies revealed that Pail is necessary for anaerobic growth of Pae on glucose in the presence of nitrate [131]. Pail was also demonstrated to impact the conversion of nitrite to nitric oxide during denitrification. However, the impact on denitrification seems to be a result of indirect effect(s) on the activity of the nitrite reductase NirS [131]. In addition, the absence of Pail resulted in impaired growth of the mutant in an in vivo CF lung infection model, highlighting the potential importance of Pail for adaptation of Pae under these conditions [131].

\subsection{NrsZ}

NrsZ represents the first reported nitrogen-regulated sRNA in PAO1, which is highly conserved among Pseudomonads [133]. It is transcribed from the ntrC-PA5126 intergenic region under nitrogen-limiting conditions by the joint action of the nitrogen-responsive TCS NtrB/C and the sigma factor RpoN $\left(\sigma^{54}, \sigma^{\mathrm{N}}\right)$ [133]. Although the NrsZ full-length transcript is $\approx 226 \mathrm{nt}$ long, the most abundant detected species are $\approx 40 \mathrm{nt}$ and $140 \mathrm{nt}$ in 
length [133]. Moreover, a processed transcript, encompassing the first $60 \mathrm{nt}$, was shown to be functional in riboregulation [133]. Thus, processing of NrsZ RNA is probably required for its activity, as it is the case with some other sRNAs such as ArcZ [134] and MicX [135]. In Pae, NrsZ promotes swarming motility by translational activation of the rhlA gene (Figure 1), the product of which is required for rhamnolipids biosynthesis [133]. Rhamnolipid biosurfactants, together with flagella, are necessary for swarming of Pae [136]. NrsZ appears to interact with an intramolecular secondary structure in the rhlA $5^{\prime} \mathrm{UTR}$ comprising the ribosome binding site (rbs) [133]. This interaction might melt the inhibitory structure and thereby promote translation of $r h l A$ mRNA [133].

\subsection{PhrS}

The PhrS RNA represents the first described anaerobically controlled sRNA in Pae [137]. PhrS synthesis is induced under hypoxic conditions [35], and requires the anaerobic regulator Anr [137]. PhrS expression is also affected by Hfq, most probably indirectly via Hfq-mediated regulation of Anr [137]. PhrS was shown to stimulate pyocyanin biosynthesis by increasing the production of PQS [137]. PhrS regulates the synthesis of PQS by indirectly activating the translation of $p q s R$ mRNA, encoding the QS regulator PqsR (MvfR) (Figure 1) [137]. PqsR acts as an activator of the pqsABCDE operon, required for biosynthesis of PQS [138]. The mechanism of PhrS-dependent translational activation of the $p q s R$ transcript includes translational coupling, whereby the translation of $p q s R$ mRNA is positively coupled with the translation of an upstream open reading frame (uof), the translation of which is stimulated by PhrS [137]. The PhrS base pairs to and resolves an inhibitory secondary structure that occludes the rbs of $u$ of, and thereby activates the translation of $u o f$, and thus of $p q s R$ mRNA [137].

Fernandez et al. [139] provided evidence for a role of PhrS in the regulation of swarming and biofilm formation. The authors observed enhanced swarming and increased biofilm biomass when the levels of PhrS were elevated. The increased levels of PhrS were in turn reconciled with elevated Hfq levels due to decreased synthesis of the Hfq-degrading protease Lon under the tested conditions [140].

A recent study proposed a novel function for PhrS as a positive regulator of CRISPRCas immunity (Figure 1) [141]. Here, PhrS is deemed to act as a transcriptional antiterminator of Rho-dependent termination by binding to the CRISPR leaders [141]. This would lead to the transcription of the CRISPR locus and synthesis of CRISPR RNA (crRNA), and thus to adaptive immunity [141].

Apart from its role as a regulatory RNA, PhrS encodes a highly conserved small 37 aa peptide $[35,137]$, and thus is regarded as a dual-function sRNA. However, the function of the peptide has so far remained elusive.

\section{Translational Repressors and Their RNA Decoys}

Pae features two comprehensive post-transcriptional networks, which are governed by $\mathrm{Hfq} / \mathrm{Crc}[29,142]$ and the CsrA-like Rsm proteins [142,143], respectively, and their antagonizing RNAs (Figure 2).

Hfq belongs to the Sm/Lsm family of RNA-binding proteins, ubiquitously present in Eukaryotes, as well as in many Eubacteria and Archaea [144,145]. It acts as a pleiotropic post-transcriptional regulator, which, in Pseudomonads, can act in concert with the catabolite repression control protein Crc [142,146-148]. Hfq-dependent regulation controls metabolism [29] and virulence traits $[47,51,124,149-151]$, including the susceptibility to clinically relevant antibiotics (Figure 3a) $[52,75,152]$. As mentioned above, Hfq can exert these functions by aiding riboregulation by sRNAs $[47,51,52,153]$, but also by directly repressing the translation of target mRNAs containing cognate Hfq-binding motifs $[29,151]$. 


\section{Translational repression of mRNA}
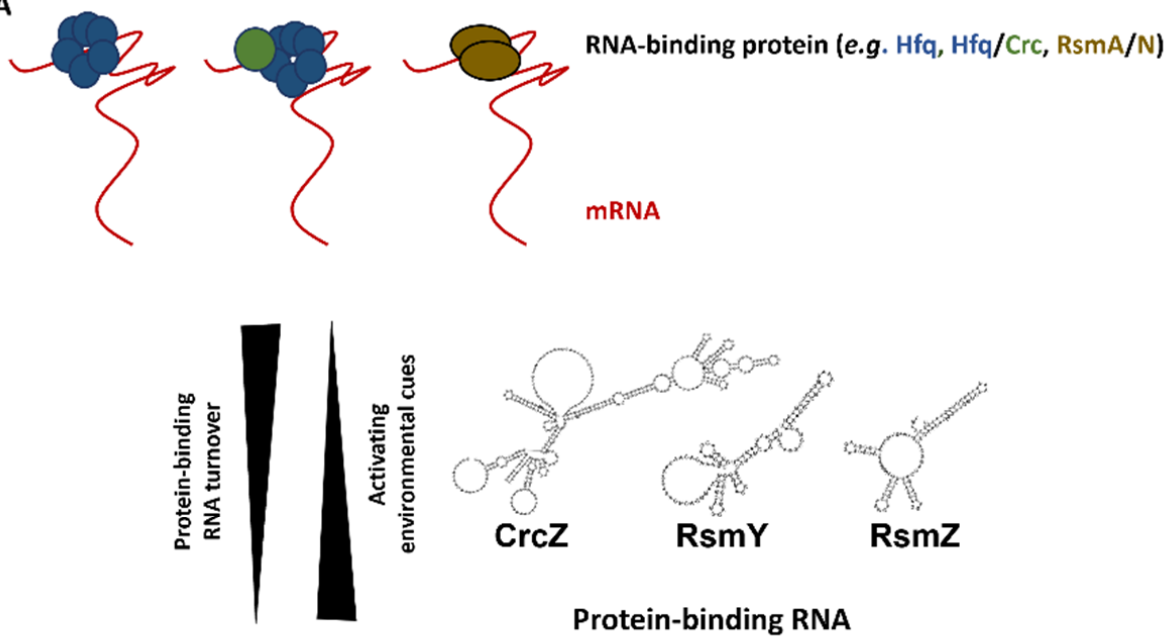

\section{Translation of mRNA}
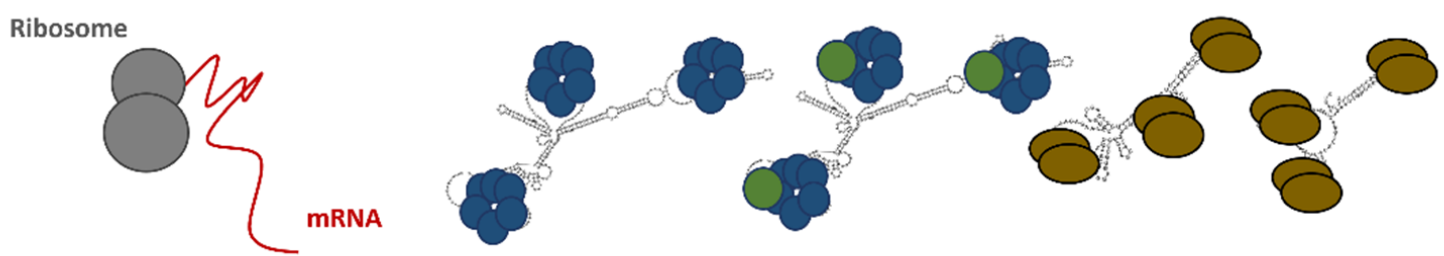

Sequestration of RNA-binding protein by protein-binding RNA

Figure 2. Regulation by protein-binding RNAs. Protein-binding RNAs (e.g., CrcZ, RsmY/Z) are activated by environmental cues. They contain multiple binding sites for RNA-binding translational repressors (top; Hfq (blue hexamer), Hfq in conjunction with Crc (blue hexamer/green circle), RsmA/N (brown circles)). This leads to sequestration of the RNA-binding proteins and to de-repression of their target mRNAs (bottom).

Many sRNAs bind to the proximal side of Hfq through either an $\mathrm{AU}_{5} \mathrm{G}-\mathrm{rich}$ sequence [154-157] or via polyU-tails of their rho-independent terminators [158-160]. Another RNA-binding surface consists of a basic arginine rich-patch located on the lateral rim of Hfq, which was found to interact with internal U/A-rich regions of sRNAs and mRNAs [49,161-164]. Moreover, RNAs can associate with the distal binding surface of Hfq $[29,148,157,165-167]$ via $\mathrm{AA}(\mathrm{R}) \mathrm{N}$ triplets, wherein $\mathrm{A}$ is an adenine, $\mathrm{R}$ is a purine and $\mathrm{N}$ is any nucleotide. Although the A-rich stretches are predominantly found in mRNAs, several studies have shown that some regulatory RNAs also contain A-rich sequences which enable interaction with the distal surface of Hfq $[29,164,168,169]$. In fact, the repressive function of $\mathrm{Hfq}$ can be antagonized through sequestration by the regulatory RNA $\mathrm{CrcZ}$, containing multiple A-rich motifs, which in turn results in de-repression of $\mathrm{Hfq}$ and $\mathrm{Hfq} / \mathrm{Crc}$ target genes (Figures 2 and $3 \mathrm{~b}$ ). 


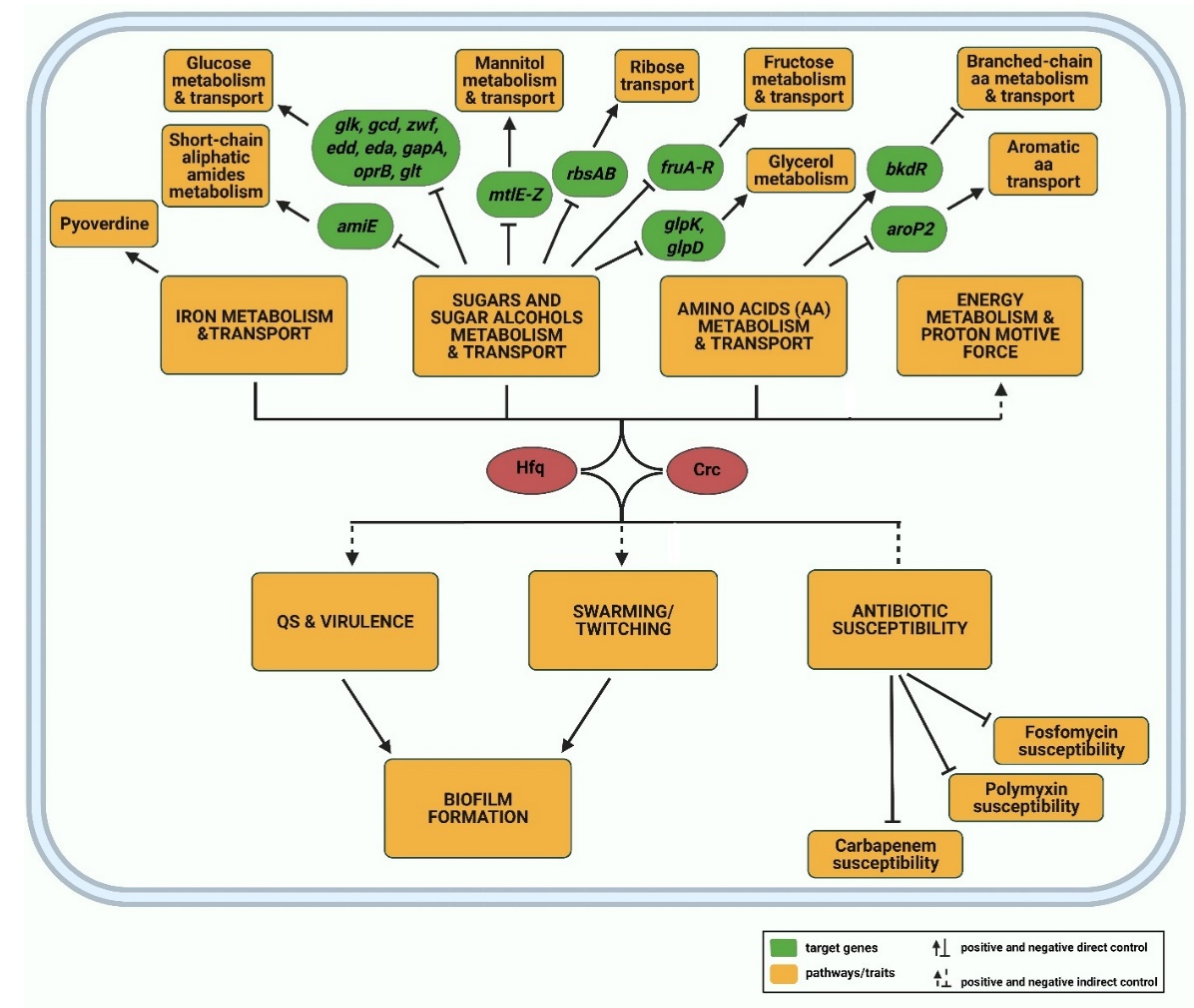

(a)

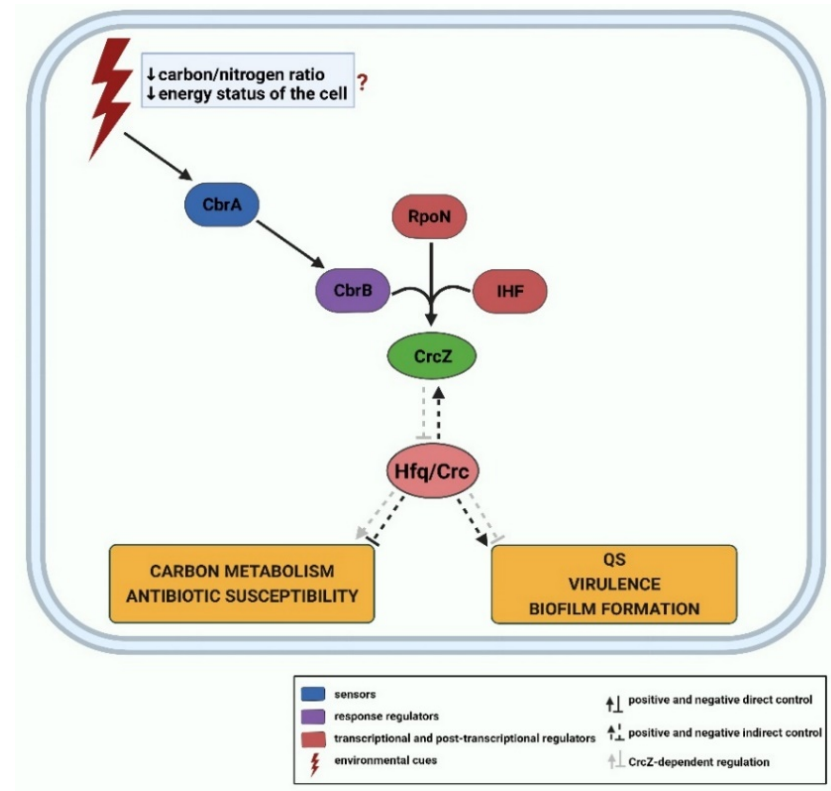

(b)

Figure 3. (a) The Hfq/Crc regulon. Hfq and Crc can exert translational repression of genes involved in carbon, iron and energy metabolism (top). In addition, they are implicated in direct (straight lines) or indirect (dashed lines) regulation of QS, virulence, antibiotic susceptibility and biofilm formation (bottom). The scheme was drawn based on previous reports [142,147,150,170-172]. (b) Transcription and stability of CrcZ RNA. The CrcZ RNA can compete for Hfq and/or $\mathrm{Hfq} / \mathrm{Crc}$ repressive complexes, and thereby cross-regulate physiological processes involved in carbon metabolism and virulence (light grey lines; (a)). The synthesis of CrcZ RNA occurs under energy-limiting conditions in the presence of an unfavorable carbon source by the joint action of the CbrA/B TCS, which is activated by a yet unknown signal (red question mark), IHF and sigma factor RpoN, $\downarrow$ : positive control; $\perp$ : negative control. 
The CsrA/RsmA family of RNA-binding proteins governs virulence gene expression in pathogenic bacteria [173-178], including Pae [139,179]. Members of this family usually negatively regulate translation of target mRNAs through binding to stem-loop structures present in their 5'UTR that contain exposed GGA motifs [27,139,173,180-184]. Rsm proteins can also act as indirect activators and repressors of a large subset of genes by altering the expression of key regulators (Figure 4a) $[139,179,185]$. Moreover, Rsm proteins can stabilize transcripts, and thereby promote their translation [184,186,187]. Analogously to the $\mathrm{Hfq} / \mathrm{Crc} / \mathrm{CrcZ}$ entity, the activity of these translational regulators can be countered by RsmA/N-binding RNAs, which act as a decoy to abrogate RsmA/N-mediated translational repression and thus, lead to de-repression of RsmA/N controlled genes (Figures 2 and $4 \mathrm{~b}$ ).

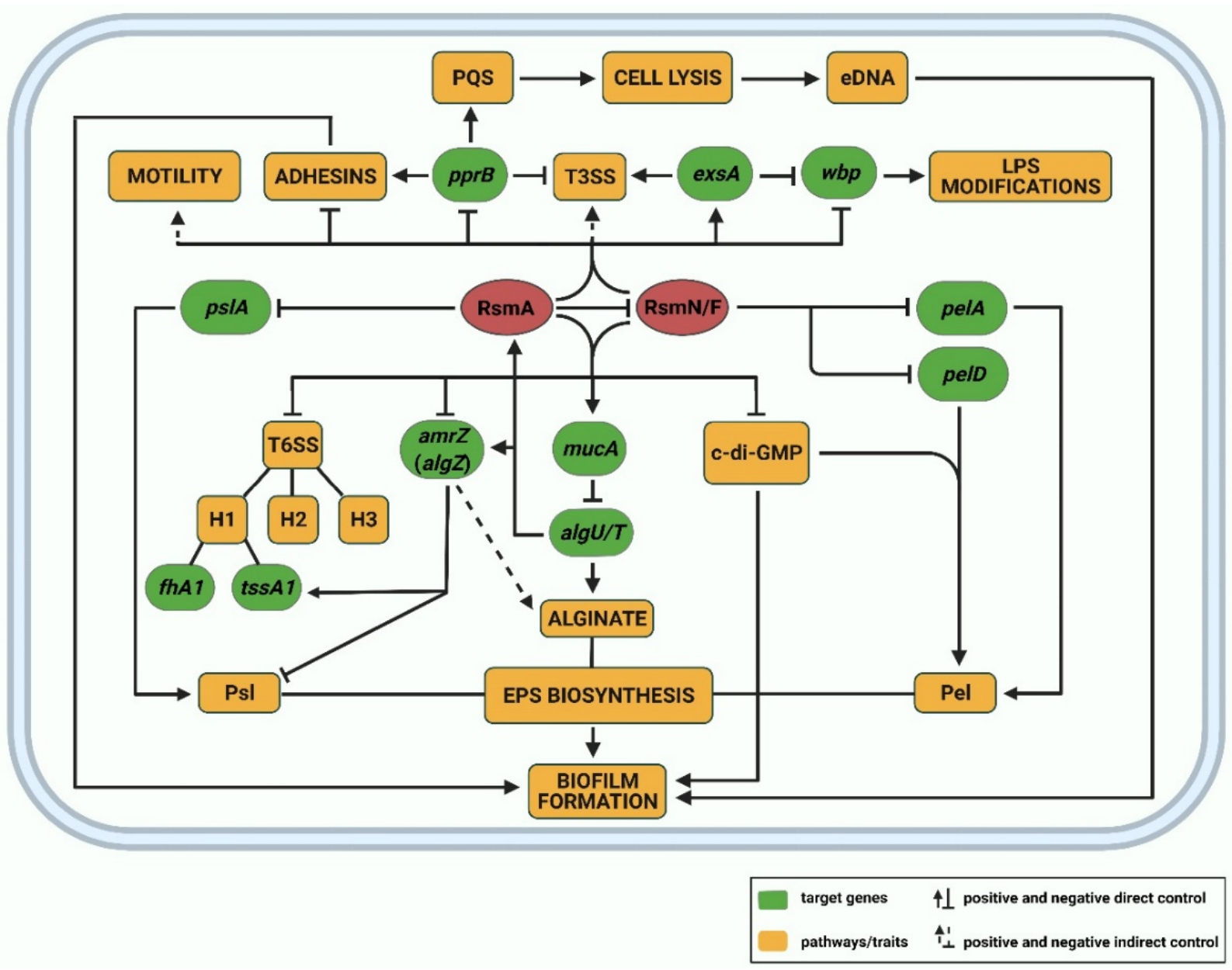

(a)

Figure 4. Cont. 


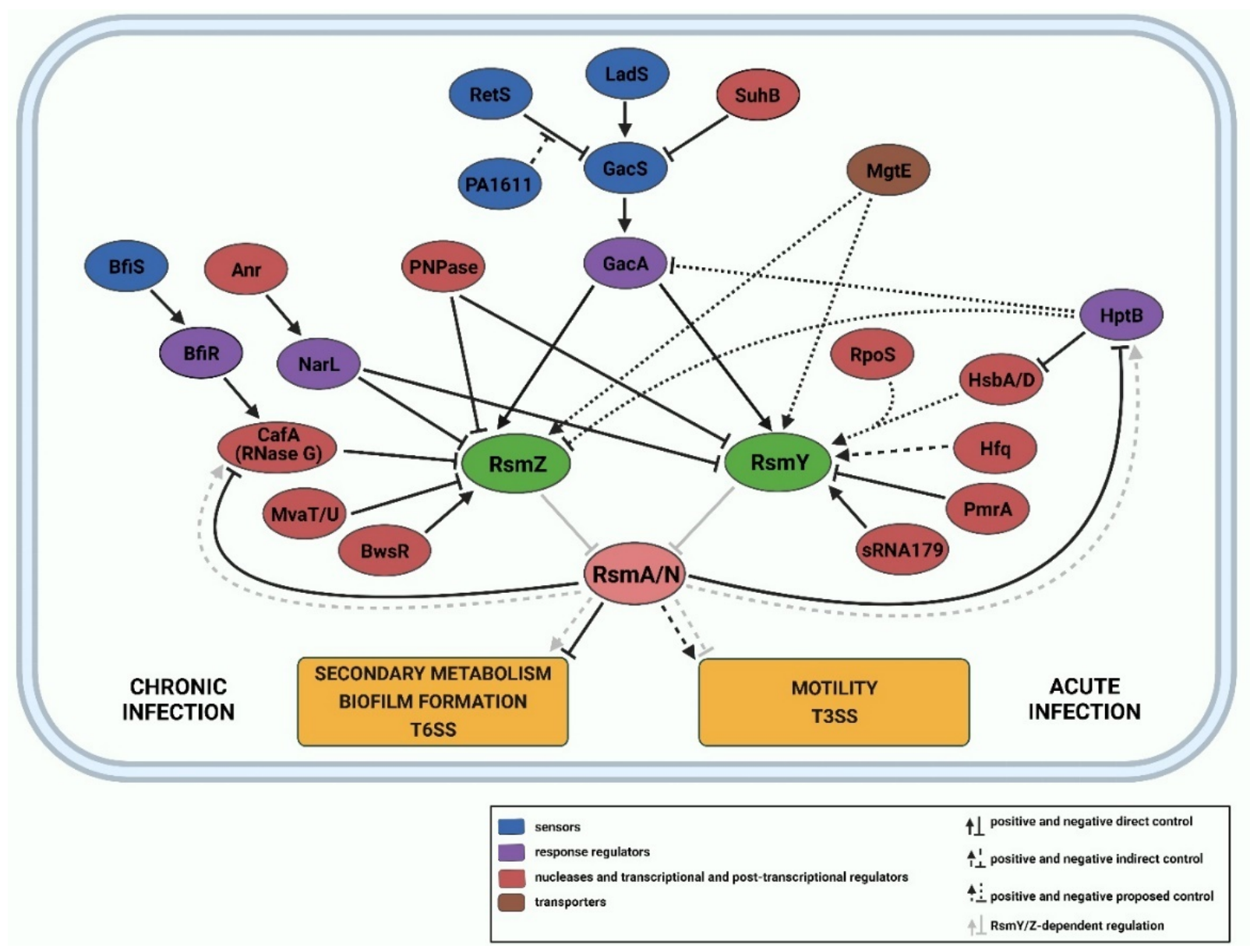

(b)

Figure 4. (a) The RsmA and RsmN/F regulons. RsmA and RsmN/F proteins can act as direct or indirect repressors or activators of different target mRNAs (in green) and pathways (in yellow), which contribute to the shift between the acute (planktonic) and the chronic (sessile, biofilm) lifestyle. RsmN/F protein synthesis is negatively controlled by RsmA at the translational level. The scheme was drawn based on previous reports $[139,143,184]$. (b) Synthesis and turnover of Rsm Y/Z RNAs. The RsmY and RsmZ RNAs serve as molecular decoys for the RsmA/N proteins, which in turn mediate the transition from an acute to the chronic infection phenotype (a). Transcription and turnover of RsmZ and RsmY are under the control of several two-component systems (sensors: blue ovals; response-regulators: violet ovals), transporters (brown ovals), nucleases and transcriptional and post-transcriptional regulators (dark red ovals), which act either in a GacA/S-dependent (e.g., SuhB-mediated repression of RsmY/Z synthesis) or independent manner (e.g., Anr-mediated repression of RsmY/Z expression). Some regulators affect the abundance of both RNAs (e.g., GacA/S transcriptional activation of RsmY/Z), whereas some are specific for only one of the RNAs (e.g., BfiR-dependent CafA degradation of RsmZ and Hfq-dependent stabilization of RsmY). The complex regulation of Rsm RNAs enables fine-tuning of the expression of RsmA/N targets in response to different environmental cues. Dashed lines: indirect control; dotted lines: proposed mechanism. Light grey lines indicate RsmY/Z-dependent regulation. Figure adapted from [188]. $\downarrow$ : positive control; $\perp$ : negative control.

\subsection{The Hfq Regulon}

In Pseudomonas, the hierarchical assimilation of carbon sources is governed by the RNA chaperone Hfq [29] and the catabolite repression control protein Crc [146,170-172,189-196] (Figure 3a). Under conditions of carbon catabolite repression (CCR), Hfq and Crc form a repressive complex on target mRNAs, the encoded proteins of which are involved in uptake and/or utilization of carbon and nitrogen sources other than the preferred one $[29,147,197]$. In the repressive complex, $\mathrm{Crc}$ acts as a translational co-repressor that promotes Hfq- 
mediated translational repression of target mRNAs [29] by binding to Hfq/mRNA complexes [147,148], thereby increasing stable Hfq/Crc/RNA complex formation [198]. A recent ChIP-seq analysis and a combined RNA-seq/proteomics study identified 100 [142] and 244 mRNAs [172], respectively, to be co-regulated by Hfq and Crc. Almost all of the nascent transcripts binding to $\mathrm{Crc}$ were also found to be associated with Hfq, emphasizing the auxiliary role of Crc in Hfq-dependent regulation [142].

Several transcriptome, proteome and metabolome analyses have implicated Hfq and Crc in the regulation of iron metabolism and transport $[150,171]$, as well as in energy metabolism and generation of the proton motive force (PMF) [150,152,170,171,196,199] (Figure 3a). Furthermore, several studies have linked Hfq with the activation of QS regulators $[147,149,150]$. A PAO1 $\Delta h f q$ deletion strain showed an increased pyocyanin production $[137,149,150]$ and an attenuated virulence phenotype $[149,150]$, the latter of which can be explained by an impairment in swarming, twitching [140] and biofilm formation [199]. Moreover, the Hfq deficiency caused an increased susceptibility to different classes of antibiotics [152] (Figure 3a). The same phenotypes were observed with a $\Delta c r c$ deletion strain [147,151,170,171,194,200,201] (Figure 3a). Many of these effects are probably indirect and are caused by de-regulation of transcription regulators and/or of the quantities of metabolites, which can act as transcription effectors [172]. However, a recent ChIPseq analysis has also provided evidence for direct regulation of some of the pathways by Hfq/Crc [142].

\subsection{CrcZ, a Decoy for $\mathrm{Hfq}$}

As mentioned above, $\mathrm{Hfq} / \mathrm{Crc}$-mediated regulation is antagonized by the Hfq-binding RNA CrcZ [29,147,193]. The CrcZ RNA is highly conserved in the genus Pseudomonas [202], and some Pseudomonas species contain additional genetically and/or functionally redundant CrcZ RNA homologs such as CrcY and CrcX in P. syringae [203,204], and CrcY in P. putida [202] and P. fluorescens [202,205], respectively. The CrcZ RNA and its homologs contain several A-rich motifs, which can interact with the distal RNA-binding surface of Hfq $[29,88,193,197,205]$. For instance, Hfq has a 5-20-fold higher affinity for CrcZ than for its target amiE mRNA, encoding an aliphatic amidase [29]. Hence, the sequestration of Hfq by CrcZ/Y prevents Hfq from binding to target mRNAs and results in translational de-repression $[29,147,196,197,205]$. In addition, through the competition for Hfq, CrcZ can also interfere with Hfq-dependent riboregulation by sRNAs [47] and hence, indirectly cross-regulate other physiologically important processes such as biofilm formation [199] and antibiotic susceptibility [75,152] (Figure 3).

In PAO1, the $407 \mathrm{nt}$ long CrcZ RNA is encoded in the $c b r B-p c n B$ intergenic region [193]. The $\operatorname{cr} Z \mathrm{Z}$ gene is transcribed from an RpoN-dependent promoter with the aid of the response regulator CbrB and integration host factor (IHF) (Figure 3b) $[193,206]$. CbrB together with its cognate histidine kinase CbrA forms a TCS involved in the maintenance of carbon and nitrogen balance $[207,208]$. CbrA/B is activated by an unknown signal, which might depend on the energy status of the cell [209]. The CbrA/B activity and the resulting CrcZ levels depend on a given carbon source [193,209]. For instance, the CrcZ levels are low during fast growth in the presence of a preferred carbon source, e.g., succinate [193,209], whereas $\mathrm{CrcZ}$ is highly abundant during slow growth in the presence of unfavorable carbon sources, e.g., oxaloacetate [209]. Hernandez-Arranz et al. [210] demonstrated that the $\operatorname{crcZ}$ expression can also be driven from the weak constitutive promoter of the $c b r B$ gene resulting in a $c b r B$-crc $Z$ transcript, which is subsequently processed to yield the $\approx 407 \mathrm{nt}$ long $\mathrm{CrcZ}$ RNA. In addition, several shorter variants of $\mathrm{CrCZ}$ seem to result from either premature termination of transcription or from degradation by a yet unknown nuclease [193]. It was further shown that Hfq in concert with Crc affects both the transcription and stability of CrcZ in P. putida [211]. 


\subsection{The RsmA and RsmN/F Regulons}

The RNA-binding proteins RsmA [212] and RsmN/F [182,213] represent two orthologs of the well-studied carbon storage regulator CsrA, which primarily serves as a translational repressor and pleiotropic regulator of various processes in E. coli [28,214-217]. RsmA and RsmN/F act in concert and have overlapping as well as unique regulatory roles (Figure 4a) $[139,182,218]$. Although the absence of RsmN/F has little or no impact on the expression of RsmA-regulated genes, the deletion of both $r s m A$ and $r s m N / F$ causes additional phenotypes when compared with a single $r s m A$ deletion [182,218]. In addition, RsmN/F and RsmA exhibit distinct binding affinities for some of their RNA targets [142,182-184,218,219]. RsmN/F binds only to targets that contain at least two Rsm consensus sequences, while RsmA requires only a single GGA motif for efficient interactions [183,184]. Moreover, RsmA functions as a translational repressor of RsmN/F (Figure 4a) [182]. Thus, RsmN/F seems to play an auxiliary role in the hierarchical Rsm regulatory cascade (Figure 4a).

The Rsm proteins govern the synthesis of many proteins involved in the transition between acute and chronic virulence phenotypes [27,139,143,174,179,182,184,185,220] (Figure 4a). For instance, they control virulence traits associated with acute infection such as the T3SS, motility and LPS modifications (Figure 4a) [139,143,184,185]. The effect of Rsm proteins on T3SS expression seems to occur through positive regulation of T3SS transcription activators [221], such as ExsA [185,222,223], and/or by inhibition of the T3SS negative regulator PprB [139,224] (Figure 4a). The Rsm-mediated regulation of motility is mainly associated with modulation of flagella and type IV pili biosynthesis [185], which appears to be indirect through the regulation of other transcriptional regulators such as AmrZ [64,143,185,225,226]. Moreover, AmrZ serves as an activator for the synthesis of the type VI secretion system (T6SS) [143,227], alginate biosynthesis [228-231] and biofilm development [232]. Vice versa, it functions as an inhibitor of flagellum synthesis [233] and exopolysaccharide Psl production [234] (Figure 4a). A recent study [185] has linked Rsm-mediated regulation with O-antigen biosynthesis and LPS modification. The $w z x$, $w z y$ and $w z z$ genes, the products of which are involved in regulation and assembly of the O-antigen, and the wbp operon, which is important for the biosynthesis and assembly of the nucleotide sugars of the O-unit [235], were found to be translationally repressed by RsmA/N (Figure 4a) [184]. This, in turn, can lead to the LPS-rough phenotype, often present in Pae isolates during chronic CF lung infections [59]. Moreover, the wzz2 expression can be transcriptionally repressed by AmrZ [236], whereas the expression of $w b p A$ and $w b p H$ genes appears to be directly governed by the T3SS transcription regulator ExsA [237] (Figure 4a). Hence, the O-antigen biosynthesis and LPS modification seems to be under both direct translational and indirect transcriptional control of Rsm proteins.

Besides their positive impact on acute virulence traits, the Rsm proteins also negatively impact features important in chronic infections, e.g., T6SS synthesis, EPS production, cdi-GMP signaling and biofilm formation [185,238-242] (Figure 4a). RsmA/N serve as translational repressors of several T6SS genes. Among them, the effect on the expression of tss $A 1$ and fha1 T6SS structural genes is well studied [143,182,185,242]. The RsmA/Nmediated repression of amrZ does not only impact motility as discussed above, but also EPS [139,143,227,232] and T6SS biosynthesis [228,229,234] (Figure 4a). Moreover, RsmA/N can directly inhibit the synthesis of EPS (Figure 4a). For instance, RsmA translationally represses pslA mRNA [243], whereas RsmN/F was shown to inhibit the synthesis of PelA and PelD [139]. Both Rsm proteins promote the expression of the $m u c A$ gene, probably by binding to and stabilizing its transcript [139]. MucA encodes an anti-sigma factor of the alternative sigma factor $\mathrm{Alg} \mathrm{U} / \mathrm{T}$, which, in addition to its role in envelope stress response, acts as a key regulator in alginate biosynthesis [244,245]. Furthermore, previous studies have implicated AlgU in promotion of $r s m A$ [246] and amrZ transcription [228], respectively (Figure 4a). In addition to the inhibition of EPS biosynthesis, which plays an important role in biofilm formation, Rsm proteins mediate the repression of other biofilmrelated pathways and regulators (Figure 4a). As mentioned above, RsmN/F inhibits 
the expression of pelD [139], which is involved in c-di-GMP-dependent regulation of Pel biosynthesis [247] (Figure 4a). The c-di-GMP signaling and Rsm regulatory network were shown to be intertwined and antagonistically regulate the shift from the motile to the sessile phenotype [248-251].

Another direct target of Rsm proteins is the response regulator PprB [139], which is not only known as a negative regulator of T3SS, but also as a positive regulator of adhesins [224], PQS-mediated cell lysis and of the release of extracellular DNA (eDNA), which contribute to biofilm formation [252] (Figure 4a).

Last but not least, Rsm proteins appear to modulate the expression of several transcripts encoding phosphodiesterases (PDEs) and diguanylate cyclases (DGCs), which impact the c-di-GMP levels, which in turn widely affects gene expression and function $[139,250]$.

\section{4. $R s m V / W / Y / Z$, Decoys for RsmA/N/F}

The function of the Rsm proteins is controlled by Rsm-binding RNAs, which act by titration [28,184,186,218,219,253]. Four RsmA- and RsmN/F-titrating RNAs, RsmZ/B [186,254], RsmY [150,255], RsmW [256] and RsmV [219], have been described in Pseudomonads. The Rsm RNAs contain multiple GGA motifs, which serve as Rsm binding sites $[27,186,218$, 219,253,255-257]. Different binding affinities of Rsm proteins for Rsm RNAs are deemed to provide a mechanism of modulating the Rsm regulatory network in response to environmental signals [218]. The sequestration of the Rsm proteins by the Rsm RNAs leads to the transition from a planktonic/acute infection phenotype to a biofilm/chronic infection phenotype (Figure $4 \mathrm{~b}$ ). At the molecular level, the transition results in differential expression of various genes including those encoding components of the T3SS and the T6SS, respectively (Figure 4b) [27,139,143,179,182,184,185,188,218,219,223,243,256,258-261].

RsmY and RsmZ are the main RsmA/N/F binding RNAs [27,185,218], while RsmV and RsmW seem to contribute to the dosage effect and temporal modulation of the RsmA/RsmN/F regulatory cascade in response to specific environmental signals in strain PAO1 $[218,219,256]$. Each Rsm RNA displays different and unique expression patterns and mechanisms for turnover and stability. For instance, the synthesis of RsmY and RsmZ is transiently elevated in late logarithmic growth phase, and then significantly increases in late stationary phase, whereas onset of $r s m W$ transcription was observed in early stationary phase [219]. On the contrary, the steady-state levels of RsmV are steadily increasing throughout growth [219]. Moreover, $r s m W, r s m Y$ and $r s m Z$ expression is elevated in biofilms [256,262]. However, RsmZ appears to repress early biofilm formation [253], highlighting the importance of controlled fine-tuning of the Rsm RNA levels [262].

The differential expression patterns of the Rsm RNAs can be attributed to distinct mechanisms of their transcription and turnover. Whereas the transcription of $r s m Y$ and rsmZ is directly controlled by the TCS GacA/S (Figure $4 b$ ) $[253,259]$ and by the two orphan sensor kinases, LadS and RetS (Figure $4 \mathrm{~b}$ ) $[238,263]$, the expression of $r s m W$ and $r s m V$ does not directly depend on the GacA/S-system [219,256]. A yet unidentified signal triggers auto-phosphorylation and the activation of the sensor kinase GacS, which in turn phosphorylates the response regulator GacA. The activity of GacS is under the control of RetS and LadS [238,263-265]. The sensor kinase RetS directly binds to GacS and impedes its auto-phosphorylation, and thus prevents subsequent activation of the response regulator GacA [266]. In contrast, the orphan kinase LadS activates the response regulator GacA by phosphorylation [267]. Thus, RetS and LadS are antagonistically driving the expression of GacA/S-dependent genes, enabling the transition between acute and chronic infection phenotypes [263]. Another study revealed that the hybrid sensor kinase PA1611 binds to RetS and interferes with its binding to GacS (Figure $4 b$ ), and thus indirectly alters the synthesis of RsmY and RsmZ RNAs [268]. Furthermore, the hybrid sensor kinase HptB was shown to negatively control rsm Y expression in planktonic cells in a GacA/S-dependent manner $[260,269]$. Recently, it was demonstrated that during stationary phase, HptB can also alter the synthesis of RsmY independently of the GacA/S regulatory cascade via an HsbA/D and RpoS-mediated pathway (Figure 4b) [270]. Moreover, HptB also inhibits 
rsmZ transcription in a GacA/S-independent way in swarming cells (Figure 4b) [269]. Similarly, the ribosome-associated protein $\mathrm{SuhB}$, which is deemed to promote synthesis of T3SS and to inhibit synthesis of T6SS, indirectly inhibits the production of RsmY and RsmZ by repressing gacA expression (Figure 4b) [271].

The transcription of $r s m Z$ and $r s m Y$ is further under control of several additional transcription regulators (e.g., Anr-mediated NarL repression of $r s m Y / Z$ expression; [272]) and transporters (e.g., MgtE-dependent activation of $r s m Y / Z$ transcription; [273]), which, in a GacA/S-independent manner, can activate or repress T3SS (Figure 4b).

In contrast to the GacA/S transcriptional activation of both RsmY and RsmZ, there are some regulatory pathways which specifically modulate the expression of only one of the RNAs in PAO1. Examples include sRNA179-mediated RsmY synthesis [274] and PmrAmediated inhibition of $r s m Y$ transcription [275] (Figure 4b), which specifically effect only the expression of RsmY, but not RsmZ. Furthermore, the histone-like nucleoid structuring proteins MvaT and MvaU were previously shown to inhibit rsmZ transcription by binding to AT-rich region upstream of the rsmZ promoter (Figure 4b) $[259,276]$. The inhibitory effects of MvaT/MvaU are in turn counteracted by the transcriptional regulator BswR (Figure 4b) [277].

The stability and turnover of RsmZ and RsmY RNAs in strain PAO1 is modulated by several regulators, which can affect the stability of both RNAs (e.g., RsmA-dependent stabilization of RsmY and RsmZ; Figure 4b; [253,278]). On the other hand, the BfiR/S-dependent CafA (RNase G) degradation affects only RsmZ during biofilm development [262] and RsmY RNA appears to be stabilized by Hfq [150,279] (Figure 4b). In addition, polynucleotide phosphorylase (PNPase), a phosphate-dependent $3^{\prime}-5^{\prime}$ exonuclease previously linked to virulence and bacterial stress response [280], was reported to regulate multiple virulence factors by affecting RsmY and RsmZ turnover [281]. It was recently demonstrated that RsmA and RsmN/F proteins can also alter rsmZ and rsm Y expression indirectly by interfering with RNase G (CafA) and HptB/HsbA/D synthesis, respectively [185] (Figure 4b).

Taken together, the transcription as well as the stability/levels of Rsm titrating RNAs are governed by numerous regulatory circuits responding to environmental cues as well as to the physiological state of the cells, which not only permits to mount an acute or a chronic infection phenotype but probably also to fine-tune their formation.

\section{Perspectives}

Many candidate regulatory RNAs have been revealed in bacteria owing to the development of novel high-throughput technologies. Recent examples include gradient profiling by sequencing (Gradseq) [282,283] or RNase-sensitive gradient profiling by mass spectrometry (GradR) [284] for the discovery of RNA/protein complexomes [284-288]. The resulting follow-up studies will certainly advance our understanding of intricate regulatory RNA-protein interacting networks in bacteria.

Unravelling the RNA-based regulation of processes controlling metabolism, cell growth, biofilm formation, antibiotic susceptibility and other virulence traits of (multi)drugresistant pathogens such as the ESKAPE class (Enterococcus faecium, Staphylococcus aureus, Klebsiella pneumoniae, Acinetobacter baumannii, Pseudomonas aeruginosa, and Enterobacter species) [289,290] will be rewarding for the development of novel antimicrobials [291,292]. Such attempts are exemplified by the development of anti-sense oligomers, especially peptide nucleic acids (PNAs), which can act as precision antimicrobials selectively targeting species-specific mRNAs under certain conditions [293-299]. PNAs and other anti-sense oligomers often show synergistic effects with existing antibiotics [300-303]. Hence, these novel insights might change the treatment of infections caused by (multi)drug-resistant pathogens [304-306] as well as by multi-species [307] during acute and chronic infections [303,308].

Moreover, the discovery of new RNA chaperones such as ProQ [282,309-314], as well as novel functions of well-known RNA-binding proteins $[315,316]$, show that the complexity of RNA-based regulation is increasing. Given the small number of characterized 
bacterial regulatory RNAs and their protein chaperones, further endeavors are required to understand RNA-mediated regulatory circuits. The continuous development of new technology to study RNA-mediated processes in conjunction with conventional biochemical and genetic approaches will certainly foster further exciting insights into RNA-based regulation in bacteria, including bacterial pathogens such as Pae.

Author Contributions: Conceptualization, P.P. and U.B.; investigation, P.P., E.S. and U.B.; writingoriginal draft preparation, P.P. and U.B.; writing — review and editing, P.P., E.S. and U.B.; visualization, P.P.; supervision, U.B.; project administration, E.S. and U.B.; funding acquisition, E.S. and U.B. All authors have read and agreed to the published version of the manuscript.

Funding: The authors were supported by the Austrian Science Fund (FWF; www.fwf.ac.at/en) through projects P28711 (U.B. and E.S.) and P33617 (U.B. and E.S.). P.P. was supported through the FWF funded doctoral program RNA-Biology W-1207.

Acknowledgments: Figures 1, 3 and 4 were created with Biorender.com, accessed on 18 July 2021. Open Access Funding by the Austrian Science Fund (FWF).

Conflicts of Interest: The authors declare no conflict of interest.

\section{References}

1. Toledo-Arana, A.; Repoila, F.; Cossart, P. Small noncoding RNAs controlling pathogenesis. Curr. Opin. Microbiol. 2007, 10, 182-188. [CrossRef]

2. Waters, L.S.; Storz, G. Regulatory RNAs in bacteria. Cell 2009, 136, 615-628. [CrossRef]

3. Holmqvist, E.; Wagner, E.G.H. Impact of bacterial sRNAs in stress responses. Biochem. Soc. Trans. 2017, 45, 1203-1212. [CrossRef]

4. Hör, J.; Vogel, J. Global snapshots of bacterial RNA networks. EMBO J. 2017, 36, 245-247. [CrossRef] [PubMed]

5. Durica-Mitic, S.; Göpel, Y.; Görke, B. Carbohydrate utilization in bacteria: Making the most out of sugars with the help of small regulatory RNAs. Microbiol. Spectr. 2018, 6, 1-19. [CrossRef]

6. Chakravarty, S.; Massé, E. RNA-dependent regulation of virulence in pathogenic bacteria. Front. Cell. Infect. Microbiol. 2019, 9, 337. [CrossRef]

7. Diallo, I.; Provost, P. RNA-sequencing analyses of small bacterial RNAs and their emergence as virulence factors in host-pathogen interactions. Int. J. Mol. Sci. 2020, 21, 1627. [CrossRef] [PubMed]

8. González Plaza, J.J. Small RNAs as fundamental players in the transference of information during bacterial infectious diseases. Front. Mol. Biosci. 2020, 7, 101. [CrossRef] [PubMed]

9. Iosub, I.A.; van Nues, R.W.; McKellar, S.W.; Nieken, K.J.; Marchioretto, M.; Sy, B.; Tree, J.J.; Viero, G.; Granneman, S. Hfq CLASH uncovers sRNA-target interaction networks linked to nutrient availability adaptation. Elife 2020, 9, e54655. [CrossRef]

10. Mediati, D.G.; Wu, S.; Wu, W.; Tree, J.J. Networks of resistance: Small RNA control of antibiotic resistance. Trends Genet. 2021, 37, 35-45. [CrossRef]

11. Sorek, R.; Cossart, P. Prokaryotic transcriptomics: A new view on regulation, physiology and pathogenicity. Nat. Rev. Genet. 2010, 11, 9-16. [CrossRef]

12. Dar, D.; Shamir, M.; Mellin, J.R.; Koutero, M.; Stern-Ginossar, N.; Cossart, P.; Sorek, R. Term-seq reveals abundant ribo-regulation of antibiotics resistance in bacteria. Science 2016, 352, aad9822. [CrossRef]

13. Wagner, E.G.H.; Romby, P. Small RNAs in bacteria and archaea: Who they are, what they do, and how they do it. Adv. Genet. 2015, 90, 133-208. [CrossRef] [PubMed]

14. Massé, E.; Escorcia, F.E.; Gottesman, S. Coupled degradation of a small regulatory RNA and its mRNA targets in Escherichia coli. Genes Dev. 2003, 17, 2374-2383. [CrossRef] [PubMed]

15. Itoh, T.; Tomizawa, J. Formation of an RNA primer for initiation of replication of ColE1 DNA by ribonuclease H. Proc. Natl. Acad. Sci. USA 1980, 77, 2450-2454. [CrossRef] [PubMed]

16. Kittle, J.D.; Simons, R.W.; Lee, J.; Kleckner, N. Insertion sequence IS10 anti-sense pairing initiates by an interaction between the $5^{\prime}$ end of the target RNA and a loop in the anti-sense RNA. J. Mol. Biol. 1989, 210, 561-572. [CrossRef]

17. Marraffini, L.A.; Sontheimer, E.J. CRISPR interference limits horizontal gene transfer in staphylococci by targeting DNA. Science 2008, 322, 1843-1845. [CrossRef] [PubMed]

18. Wassarman, K.M. 6S RNA: A regulator of transcription. Mol. Microbiol. 2007, 65, 1425-1431. [CrossRef]

19. Wassarman, K.M. 6S RNA: A small RNA regulator of transcription. Curr. Opin. Microbiol. 2007, 10, 164-168. [CrossRef]

20. Sedlyarova, N.; Shamovsky, I.; Bharati, B.K.; Epshtein, V.; Chen, J.; Gottesman, S.; Schroeder, R.; Nudler, E. sRNA-mediated control of transcription termination in E. coli. Cell 2016, 167, 111-121. [CrossRef]

21. Wassarman, K.M. 6S RNA, a global regulator of transcription. Microbiol. Spectr. 2018, 6, 355-367. [CrossRef] [PubMed]

22. Chen, J.; Morita, T.; Gottesman, S. Regulation of transcription termination of small RNAs and by small RNAs: Molecular mechanisms and biological functions. Front. Cell. Infect. Microbiol. 2019, 9, 201. [CrossRef] [PubMed] 
23. Storz, G.; Vogel, J.; Wassarman, K.M. Regulation by small RNAs in bacteria: Expanding frontiers. Mol. Cell 2011, $43,880-891$. [CrossRef] [PubMed]

24. Papenfort, K.; Vanderpool, C.K. Target activation by regulatory RNAs in bacteria. FEMS Microbiol. Rev. 2015, 39, 362-378. [CrossRef]

25. Jørgensen, M.G.; Pettersen, J.S.; Kallipolitis, B.H. sRNA-mediated control in bacteria: An increasing diversity of regulatory mechanisms. Biochim. Biophys. Acta Gene Regul. Mech. 2020, 1863, 194504. [CrossRef] [PubMed]

26. Babitzke, P.; Romeo, T. CsrB sRNA family: Sequestration of RNA-binding regulatory proteins. Curr. Opin. Microbiol. 2007, 10, 156-163. [CrossRef] [PubMed]

27. Lapouge, K.; Schubert, M.; Allain, F.H.-T.; Haas, D. Gac/Rsm signal transduction pathway of gamma-proteobacteria: From RNA recognition to regulation of social behaviour. Mol. Microbiol. 2008, 67, 241-253. [CrossRef]

28. Romeo, T.; Babitzke, P. Global regulation by CsrA and its RNA antagonists. Microbiol. Spectr. 2018, 6, 1-13. [CrossRef]

29. Sonnleitner, E.; Bläsi, U. Regulation of Hfq by the RNA CrcZ in Pseudomonas aeruginosa carbon catabolite repression. PLoS Genet. 2014, 10, e1004440. [CrossRef]

30. Azam, M.S.; Vanderpool, C.K. Talk among yourselves: RNA sponges mediate cross talk between functionally related messenger RNAs. EMBO J. 2015, 34, 1436-1438. [CrossRef]

31. Miyakoshi, M.; Chao, Y.; Vogel, J. Cross talk between ABC transporter mRNAs via a target mRNA-derived sponge of the GcvB small RNA. EMBO J. 2015, 34, 1478-1492. [CrossRef]

32. Denham, E.L. The Sponge RNAs of bacteria-How to find them and their role in regulating the post-transcriptional network. Biochim. Biophys. Acta Gene Regul. Mech. 2020, 1863, 194565. [CrossRef]

33. Wilderman, P.J.; Sowa, N.A.; FitzGerald, D.J.; FitzGerald, P.C.; Gottesman, S.; Ochsner, U.A.; Vasil, M.L. Identification of tandem duplicate regulatory small RNAs in Pseudomonas aeruginosa involved in iron homeostasis. Proc. Natl. Acad. Sci. USA 2004, 101, 9792-9797. [CrossRef]

34. Livny, J.; Brencic, A.; Lory, S.; Waldor, M.K. Identification of 17 Pseudomonas aeruginosa sRNAs and prediction of sRNA-encoding genes in 10 diverse pathogens using the bioinformatic tool sRNAPredict2. Nucleic Acids Res. 2006, 34, 3484-3493. [CrossRef]

35. Sonnleitner, E.; Sorger-Domenigg, T.; Madej, M.J.; Findeiss, S.; Hackermuller, J.; Huttenhofer, A.; Stadler, P.F.; Blasi, U.; Moll, I. Detection of small RNAs in Pseudomonas aeruginosa by RNomics and structure-based bioinformatic tools. Microbiology 2008, 154, 3175-3187. [CrossRef] [PubMed]

36. Dötsch, A.; Eckweiler, D.; Schniederjans, M.; Zimmermann, A.; Jensen, V.; Scharfe, M.; Geffers, R.; Häussler, S. The Pseudomonas aeruginosa transcriptome in planktonic cultures and static biofilms using RNA sequencing. PLoS ONE 2012, 7, e31092. [CrossRef] [PubMed]

37. Ferrara, S.; Brugnoli, M.; De Bonis, A.; Righetti, F.; Delvillani, F.; Deho, G.; Horner, D.; Briani, F.; Bertoni, G. Comparative profiling of Pseudomonas aeruginosa strains reveals differential expression of novel unique and conserved small RNAs. PLoS ONE 2012, 7, e36553. [CrossRef] [PubMed]

38. Gomez-Lozano, M.; Marvig, R.L.; Molin, S.; Long, K.S. Genome-wide identification of novel small RNAs in Pseudomonas aeruginosa. Environ. Microbiol. 2012, 14, 2006-2016. [CrossRef] [PubMed]

39. Wurtzel, O.; Yoder-Himes, D.R.; Han, K.; Dandekar, A.A.; Edelheit, S.; Greenberg, E.P.; Sorek, R.; Lory, S. The single-nucleotide resolution transcriptome of Pseudomonas aeruginosa grown in body temperature. PLoS Pathog. 2012, 8, e1002945. [CrossRef]

40. Gomez-Lozano, M.; Marvig, R.L.; Molina-Santiago, C.; Tribelli, P.M.; Ramos, J.-L.; Molin, S. Diversity of small RNAs expressed in Pseudomonas species. Environ. Microbiol. Rep. 2015, 7, 227-236. [CrossRef]

41. Pita, T.; Feliciano, J.R.; Leitão, J.H. Small noncoding regulatory RNAs from Pseudomonas aeruginosa and Burkholderia cepacia complex. Int. J. Mol. Sci. 2018, 19, 3759. [CrossRef] [PubMed]

42. Li, L.; Huang, D.; Cheung, M.K.; Nong, W.; Huang, Q.; Kwan, H.S. BSRD: A repository for bacterial small regulatory RNA. Nucleic Acids Res. 2013, 41, D233-D238. [CrossRef] [PubMed]

43. Van Assche, E.; Van Puyvelde, S.; Vanderleyden, J.; Steenackers, H.P. RNA-binding proteins involved in post-transcriptional regulation in bacteria. Front. Microbiol. 2015, 6, 141. [CrossRef] [PubMed]

44. Woodson, S.A.; Panja, S.; Santiago-Frangos, A. Proteins that chaperone RNA regulation. Microbiol. Spectr. 2018, 6, 1-13. [CrossRef] [PubMed]

45. Holmqvist, E.; Vogel, J. RNA-binding proteins in bacteria. Nat. Rev. Microbiol. 2018, 16, 601-615. [CrossRef]

46. Quendera, A.P.; Seixas, A.F.; dos Santos, R.F.; Santos, I.; Silva, J.P.N.; Arraiano, C.M.; Andrade, J.M. RNA-binding proteins driving the regulatory activity of small non-coding RNAs in bacteria. Front. Mol. Biosci. 2020, 7, 78. [CrossRef]

47. Sonnleitner, E.; Prindl, K.; Bläsi, U. The Pseudomonas aeruginosa CrcZ RNA interferes with Hfq-mediated riboregulation. PLoS ONE 2017, 12, e0180887. [CrossRef]

48. Vogel, J.; Luisi, B.F. Hfq and its constellation of RNA. Nat. Rev. Microbiol. 2011, 9, 578-589. [CrossRef]

49. Santiago-Frangos, A.; Woodson, S.A. Hfq chaperone brings speed dating to bacterial sRNA. Wiley Interdiscip. Rev. RNA 2018, 9 , e1475. [CrossRef]

50. Gottesman, S.; McCullen, C.A.; Guillier, M.; Vanderpool, C.K.; Majdalani, N.; Benhammou, J.; Thompson, K.M.; FitzGerald, P.C.; Sowa, N.A.; FitzGerald, D.J. Small RNA regulators and the bacterial response to stress. Cold Spring Harb. Symp. Quant. Biol. 2006, 71,1-11. [CrossRef] [PubMed] 
51. Ferrara, S.; Carloni, S.; Fulco, R.; Falcone, M.; Macchi, R.; Bertoni, G. Post-transcriptional regulation of the virulence-associated enzyme AlgC by the sigma(22) -dependent small RNA ErsA of Pseudomonas aeruginosa. Environ. Microbiol. 2015, 17, 199-214. [CrossRef] [PubMed]

52. Zhang, Y.F.; Han, K.; Chandler, C.E.; Tjaden, B.; Ernst, R.K.; Lory, S. Probing the sRNA regulatory landscape of P. aeruginosa: Post-transcriptional control of determinants of pathogenicity and antibiotic susceptibility. Mol. Microbiol. 2017, 106, 919-937. [CrossRef]

53. Padgett, P.J.; Phibbs, P.V. Phosphomannomutase activity in wild-type and alginate-producing strains of Pseudomonas aeruginosa. Curr. Microbiol. 1986, 14, 187-192. [CrossRef]

54. Sá-Correia, I.; Darzins, A.; Wang, S.K.; Berry, A.; Chakrabarty, A.M. Alginate biosynthetic enzymes in mucoid and nonmucoid Pseudomonas aeruginosa: Overproduction of phosphomannose isomerase, phosphomannomutase, and GDP-mannose pyrophosphorylase by overexpression of the phosphomannose isomerase (pmi) gene. J. Bacteriol. 1987, 169, 3224-3231. [CrossRef]

55. Ma, L.; Wang, J.; Wang, S.; Anderson, E.M.; Lam, J.S.; Parsek, M.R.; Wozniak, D.J. Synthesis of multiple Pseudomonas aeruginosa biofilm matrix exopolysaccharides is post-transcriptionally regulated. Environ. Microbiol. 2012, 14, 1995-2005. [CrossRef] [PubMed]

56. Goldberg, J.B.; Hatano, K.; Pier, G.B. Synthesis of lipopolysaccharide O side chains by Pseudomonas aeruginosa PAO1 requires the enzyme phosphomannomutase. J. Bacteriol. 1993, 175, 1605-1611. [CrossRef]

57. Coyne, M.J.J.; Russell, K.S.; Coyle, C.L.; Goldberg, J.B. The Pseudomonas aeruginosa algC gene encodes phosphoglucomutase, required for the synthesis of a complete lipopolysaccharide core. J. Bacteriol. 1994, 176, 3500-3507. [CrossRef]

58. Olvera, C.; Goldberg, J.B.; Sánchez, R.; Soberón-Chávez, G. The Pseudomonas aeruginosa algC gene product participates in rhamnolipid biosynthesis. FEMS Microbiol. Lett. 1999, 179, 85-90. [CrossRef]

59. Deretic, V.; Schurr, M.J.; Yu, H. Pseudomonas aeruginosa, mucoidy and the chronic infection phenotype in cystic fibrosis. Trends Microbiol. 1995, 3, 351-356. [CrossRef]

60. Wang, S.; Yu, S.; Zhang, Z.; Wei, Q.; Yan, L.; Ai, G.; Liu, H.; Ma, L.Z. Coordination of swarming motility, biosurfactant synthesis, and biofilm matrix exopolysaccharide production in Pseudomonas aeruginosa. Appl. Environ. Microbiol. 2014, 80, 6724-6732. [CrossRef] [PubMed]

61. Zielinski, N.A.; Chakrabarty, A.M.; Berry, A. Characterization and regulation of the Pseudomonas aeruginosa algC gene encoding phosphomannomutase. J. Biol. Chem. 1991, 266, 9754-9763. [CrossRef]

62. Zielinski, N.A.; Maharaj, R.; Roychoudhury, S.; Danganan, C.E.; Hendrickson, W.; Chakrabarty, A.M. Alginate synthesis in Pseudomonas aeruginosa: Environmental regulation of the algC promoter. J. Bacteriol. 1992, 174, 7680-7688. [CrossRef] [PubMed]

63. Lizewski, S.E.; Lundberg, D.S.; Schurr, M.J. The transcriptional regulator AlgR is essential for Pseudomonas aeruginosa pathogenesis. Infect. Immun. 2002, 70, 6083-6093. [CrossRef]

64. Falcone, M.; Ferrara, S.; Rossi, E.; Johansen, H.K.; Molin, S.; Bertoni, G. The small RNA ErsA of Pseudomonas aeruginosa contributes to biofilm development and motility through post-transcriptional modulation of AmrZ. Front. Microbiol. 2018, 9, 238. [CrossRef] [PubMed]

65. Ferrara, S.; Rossi, A.; Ranucci, S.; De Fino, I.; Bragonzi, A.; Cigana, C.; Bertoni, G. The small RNA ErsA plays a role in the regulatory network of Pseudomonas aeruginosa pathogenicity in airway infections. mSphere 2020, 5, e00909-20. [CrossRef] [PubMed]

66. Trias, J.; Nikaido, H. Protein D2 channel of the Pseudomonas aeruginosa outer membrane has a binding site for basic amino acids and peptides. J. Biol. Chem. 1990, 265, 15680-15684. [CrossRef]

67. Trias, J.; Nikaido, H. Outer membrane protein D2 catalyzes facilitated diffusion of carbapenems and penems through the outer membrane of Pseudomonas aeruginosa. Antimicrob. Agents Chemother. 1990, 34, 52-57. [CrossRef]

68. Henrichfreise, B.; Wiegand, I.; Pfister, W.; Wiedemann, B. Resistance mechanisms of multiresistant Pseudomonas aeruginosa strains from Germany and correlation with hypermutation. Antimicrob. Agents Chemother. 2007, 51, 4062-4070. [CrossRef]

69. Diene, S.M.; L’homme, T.; Bellulo, S.; Stremler, N.; Dubus, J.-C.; Mely, L.; Leroy, S.; Degand, N.; Rolain, J.-M. ISPa46, a novel insertion sequence in the oprD porin gene of an imipenem-resistant Pseudomonas aeruginosa isolate from a cystic fibrosis patient in Marseille, France. Int. J. Antimicrob. Agents 2013, 42, 268-271. [CrossRef] [PubMed]

70. Llanes, C.; Pourcel, C.; Richardot, C.; Plésiat, P.; Fichant, G.; Cavallo, J.-D.; Mérens, A. Diversity of $\beta$-lactam resistance mechanisms in cystic fibrosis isolates of Pseudomonas aeruginosa: A French multicentre study. J. Antimicrob. Chemother. 2013, 68, $1763-1771$. [CrossRef] [PubMed]

71. Richardot, C.; Plésiat, P.; Fournier, D.; Monlezun, L.; Broutin, I.; Llanes, C. Carbapenem resistance in cystic fibrosis strains of Pseudomonas aeruginosa as a result of amino acid substitutions in porin OprD. Int. J. Antimicrob. Agents 2015, 45, 529-532. [CrossRef]

72. Chalhoub, H.; Sáenz, Y.; Rodriguez-Villalobos, H.; Denis, O.; Kahl, B.C.; Tulkens, P.M.; Van Bambeke, F. High-level resistance to meropenem in clinical isolates of Pseudomonas aeruginosa in the absence of carbapenemases: Role of active efflux and porin alterations. Int. J. Antimicrob. Agents 2016, 48, 740-743. [CrossRef]

73. Courtois, N.; Caspar, Y.; Maurin, M. Phenotypic and genetic resistance traits of Pseudomonas aeruginosa strains infecting cystic fibrosis patients: A French cohort study. Int. J. Antimicrob. Agents 2018, 52, 358-364. [CrossRef]

74. Sherrard, L.J.; Wee, B.A.; Duplancic, C.; Ramsay, K.A.; Dave, K.A.; Ballard, E.; Wainwright, C.E.; Grimwood, K.; Sidjabat, H.E.; Whiley, D.M.; et al. Emergence and impact of oprD mutations in Pseudomonas aeruginosa strains in cystic fibrosis. J. Cyst. Fibros. Off. J. Eur. Cyst. Fibros. Soc. 2021. [CrossRef] [PubMed] 
75. Sonnleitner, E.; Pusic, P.; Wolfinger, M.T.; Bläsi, U. Distinctive regulation of carbapenem susceptibility in Pseudomonas aeruginosa by Hfq. Front. Microbiol. 2020, 11, 1001. [CrossRef] [PubMed]

76. Ernst, R.K.; Yi, E.C.; Guo, L.; Lim, K.B.; Burns, J.L.; Hackett, M.; Miller, S.I. Specific lipopolysaccharide found in cystic fibrosis airway Pseudomonas aeruginosa. Science 1999, 286, 1561-1565. [CrossRef] [PubMed]

77. Ernst, R.K.; Hajjar, A.M.; Tsai, J.H.; Moskowitz, S.M.; Wilson, C.B.; Miller, S.I. Pseudomonas aeruginosa lipid A diversity and its recognition by Toll-like receptor 4. J. Endotoxin Res. 2003, 9, 395-400. [CrossRef]

78. Ernst, R.K.; Adams, K.N.; Moskowitz, S.M.; Kraig, G.M.; Kawasaki, K.; Stead, C.M.; Trent, M.S.; Miller, S.I. The Pseudomonas aeruginosa lipid A deacylase: Selection for expression and loss within the cystic fibrosis airway. J. Bacteriol. 2006, 188, $191-201$. [CrossRef]

79. Kawasaki, K.; China, K.; Nishijima, M. Release of the lipopolysaccharide deacylase PagL from latency compensates for a lack of lipopolysaccharide aminoarabinose modification-dependent resistance to the antimicrobial peptide polymyxin B in Salmonella enterica. J. Bacteriol. 2007, 189, 4911-4919. [CrossRef]

80. Han, M.-L.; Velkov, T.; Zhu, Y.; Roberts, K.D.; Le Brun, A.P.; Chow, S.H.; Gutu, A.D.; Moskowitz, S.M.; Shen, H.-H.; Li, J. Polymyxin-induced lipid A deacylation in Pseudomonas aeruginosa perturbs polymyxin penetration and confers high-level resistance. ACS Chem. Biol. 2018, 13, 121-130. [CrossRef] [PubMed]

81. Moskowitz, S.M.; Ernst, R.K. The role of Pseudomonas lipopolysaccharide in cystic fibrosis airway infection. Subcell. Biochem. 2010, 53, 241-253. [CrossRef]

82. Massé, E.; Gottesman, S. A small RNA regulates the expression of genes involved in iron metabolism in Escherichia coli. Proc. Natl. Acad. Sci. USA 2002, 99, 4620-4625. [CrossRef] [PubMed]

83. Gaballa, A.; Antelmann, H.; Aguilar, C.; Khakh, S.K.; Song, K.-B.; Smaldone, G.T.; Helmann, J.D. The Bacillus subtilis iron-sparing response is mediated by a Fur-regulated small RNA and three small, basic proteins. Proc. Natl. Acad. Sci. USA 2008, 105, 11927-11932. [CrossRef]

84. Vasil, M.L. How we learnt about iron acquisition in Pseudomonas aeruginosa: A series of very fortunate events. Biometals Int. J. Role Met. Ions Biol. Biochem. Med. 2007, 20, 587-601. [CrossRef] [PubMed]

85. Oglesby, A.G.; Farrow, J.M., 3rd; Lee, J.-H.; Tomaras, A.P.; Greenberg, E.P.; Pesci, E.C.; Vasil, M.L. The influence of iron on Pseudomonas aeruginosa physiology: A regulatory link between iron and quorum sensing. J. Biol. Chem. 2008, 283, 15558-15567. [CrossRef]

86. Han, K.; Tjaden, B.; Lory, S. GRIL-seq provides a method for identifying direct targets of bacterial small regulatory RNA by in vivo proximity ligation. Nat. Microbiol. 2016, 2, 16239. [CrossRef] [PubMed]

87. Arrieta-Ortiz, M.L.; Hafemeister, C.; Shuster, B.; Baliga, N.S.; Bonneau, R.; Eichenberger, P. Inference of bacterial small RNA regulatory networks and integration with transcription factor-driven regulatory networks. mSystems 2020, 5, e00057-20. [CrossRef]

88. Chihara, K.; Bischler, T.; Barquist, L.; Monzon, V.A.; Noda, N.; Vogel, J.; Tsuneda, S. Conditional Hfq association with small noncoding RNAs in Pseudomonas aeruginosa revealed through comparative UV cross-linking immunoprecipitation followed by high-throughput sequencing. mSystems 2019, 4, e00590-19. [CrossRef] [PubMed]

89. Pesci, E.C.; Milbank, J.B.J.; Pearson, J.P.; McKnight, S.; Kende, A.S.; Greenberg, E.P.; Iglewski, B.H. Quinolone signaling in the cell-to-cell communication system of Pseudomonas aeruginosa. Proc. Natl. Acad. Sci. USA 1999, 96, 11229-11234. [CrossRef]

90. McKnight, S.L.; Iglewski, B.H.; Pesci, E.C. The Pseudomonas quinolone signal regulates rhl quorum sensing in Pseudomonas aeruginosa. J. Bacteriol. 2000, 182, 2702-2708. [CrossRef]

91. Dubern, J.-F.; Diggle, S.P. Quorum sensing by 2-alkyl-4-quinolones in Pseudomonas aeruginosa and other bacterial species. Mol. BioSyst. 2008, 4, 882-888. [CrossRef] [PubMed]

92. Hänsch, G.M.; Prior, B.; Brenner-Weiss, G.; Obst, U.; Overhage, J. The Pseudomonas quinolone signal (PQS) stimulates chemotaxis of polymorphonuclear neutrophils. J. Appl. Biomater. Funct. Mater. 2014, 12, 21-26. [CrossRef]

93. Reinhart, A.A.; Nguyen, A.T.; Brewer, L.K.; Bevere, J.; Jones, J.W.; Kane, M.A.; Damron, F.H.; Barbier, M.; Oglesby-Sherrouse, A.G. The Pseudomonas aeruginosa PrrF small RNAs regulate iron homeostasis during acute murine lung infection. Infect. Immun. 2017, 85, e00764-16. [CrossRef]

94. Djapgne, L.; Panja, S.; Brewer, L.K.; Gans, J.H.; Kane, M.A.; Woodson, S.A.; Oglesby-Sherrouse, A.G. The Pseudomonas aeruginosa PrrF1 and PrrF2 small regulatory RNAs promote 2-alkyl-4- quinolone production through redundant regulation of the antR mRNA. J. Bacteriol. 2018, 200, e00704-17. [CrossRef]

95. Nelson, C.E.; Huang, W.; Brewer, L.K.; Nguyen, A.T.; Kane, M.A.; Wilks, A.; Oglesby-Sherrouse, A.G. Proteomic analysis of the Pseudomonas aeruginosa iron starvation response reveals PrrF small regulatory RNA-dependent iron regulation of twitching motility, amino acid metabolism, and zinc homeostasis proteins. J. Bacteriol. 2019, 201, e00754-1. [CrossRef] [PubMed]

96. Oglesby-Sherrouse, A.G.; Vasil, M.L. Characterization of a heme-regulated non-coding RNA encoded by the prrF locus of Pseudomonas aeruginosa. PLoS ONE 2010, 5, e9930. [CrossRef]

97. Osborne, J.; Djapgne, L.; Tran, B.Q.; Goo, Y.A.; Oglesby-Sherrouse, A.G. A method for in vivo identification of bacterial small RNA-binding proteins. Microbiologyopen 2014, 3, 950-960. [CrossRef]

98. Kawasaki, S.; Arai, H.; Kodama, T.; Igarashi, Y. Gene cluster for dissimilatory nitrite reductase (nir) from Pseudomonas aeruginosa: Sequencing and identification of a locus for heme $d 1$ biosynthesis. J. Bacteriol. 1997, 179, 235-242. [CrossRef] 
99. Reinhart, A.A.; Powell, D.A.; Nguyen, A.T.; O’Neill, M.; Djapgne, L.; Wilks, A.; Ernst, R.K.; Oglesby-Sherrouse, A.G. The prrF-encoded small regulatory RNAs are required for iron homeostasis and virulence of Pseudomonas aeruginosa. Infect. Immun. 2015, 83, 863-875. [CrossRef]

100. O'Neill, M.J.; Wilks, A. The P. aeruginosa heme binding protein PhuS is a heme oxygenase titratable regulator of heme uptake. ACS Chem. Biol. 2013, 8, 1794-1802. [CrossRef]

101. Llamas, M.A.; van der Sar, A.; Chu, B.C.H.; Sparrius, M.; Vogel, H.J.; Bitter, W. A Novel extracytoplasmic function (ECF) sigma factor regulates virulence in Pseudomonas aeruginosa. PLoS Pathog. 2009, 5, e1000572. [CrossRef]

102. Quesada, J.M.; Otero-Asman, J.R.; Bastiaansen, K.C.; Civantos, C.; Llamas, M.A. The activity of the Pseudomonas aeruginosa virulence regulator $\sigma($ VreI $)$ is modulated by the anti- $\sigma$ factor VreR and the transcription factor PhoB. Front. Microbiol. 2016, 7, 1159. [CrossRef] [PubMed]

103. Otero-Asman, J.R.; Quesada, J.M.; Jim, K.K.; Ocampo-Sosa, A.; Civantos, C.; Bitter, W.; Llamas, M.A. The extracytoplasmic function sigma factor $\sigma$ VreI is active during infection and contributes to phosphate starvation-induced virulence of Pseudomonas aeruginosa. Sci. Rep. 2020, 10, 3139. [CrossRef] [PubMed]

104. Sorger-Domenigg, T. Novel Pseudomonas aeruginosa Small Regulatory RNAs. Ph.D. Thesis, University of Vienna, Vienna, Austria, 2010.

105. Carloni, S.; Macchi, R.; Sattin, S.; Ferrara, S.; Bertoni, G. The small RNA ReaL: A novel regulatory element embedded in the Pseudomonas aeruginosa quorum sensing networks. Environ. Microbiol. 2017, 19, 4220-4237. [CrossRef]

106. Thi Bach Nguyen, H.; Romero A., D.; Amman, F.; Sorger-Domenigg, T.; Tata, M.; Sonnleitner, E.; Bläsi, U. Negative control of RpoS synthesis by the sRNA ReaL in Pseudomonas aeruginosa. Front. Microbiol. 2018, 9, 2488. [CrossRef]

107. Xia, Y.; Weng, Y.; Xu, C.; Wang, D.; Pan, X.; Tian, Z.; Xia, B.; Li, H.; Chen, R.; Liu, C.; et al. Endoribonuclease YbeY is essential for RNA processing and virulence in Pseudomonas aeruginosa. MBio 2020, 11, e00659-20. [CrossRef]

108. Lee, J.; Zhang, L. The hierarchy quorum sensing network in Pseudomonas aeruginosa. Protein Cell 2015, 6, 26-41. [CrossRef]

109. Häussler, S.; Becker, T. The Pseudomonas quinolone signal (PQS) balances life and death in Pseudomonas aeruginosa populations. PLoS Pathog. 2008, 4, e1000166. [CrossRef] [PubMed]

110. Lin, J.; Cheng, J.; Wang, Y.; Shen, X. The Pseudomonas quinolone signal (PQS): Not just for quorum sensing anymore. Front. Cell. Infect. Microbiol. 2018, 8, 230. [CrossRef]

111. Diggle, S.P.; Cornelis, P.; Williams, P.; Cámara, M. 4-quinolone signalling in Pseudomonas aeruginosa: Old molecules, new perspectives. Int. J. Med. Microbiol. 2006, 296, 83-91. [CrossRef] [PubMed]

112. Yang, L.; Nilsson, M.; Gjermansen, M.; Givskov, M.; Tolker-Nielsen, T. Pyoverdine and PQS mediated subpopulation interactions involved in Pseudomonas aeruginosa biofilm formation. Mol. Microbiol. 2009, 74, 1380-1392. [CrossRef]

113. Guo, Q.; Kong, W.; Jin, S.; Chen, L.; Xu, Y.; Duan, K. PqsR-dependent and PqsR-independent regulation of motility and biofilm formation by PQS in Pseudomonas aeruginosa PAO1. J. Basic Microbiol. 2014, 54, 633-643. [CrossRef] [PubMed]

114. Meyer, J.M.; Neely, A.; Stintzi, A.; Georges, C.; Holder, I.A. Pyoverdin is essential for virulence of Pseudomonas aeruginosa. Infect. Immun. 1996, 64, 518-523. [CrossRef]

115. Lau, G.W.; Ran, H.; Kong, F.; Hassett, D.J.; Mavrodi, D. Pseudomonas aeruginosa pyocyanin is critical for lung infection in mice. Infect. Immun. 2004, 72, 4275-4278. [CrossRef]

116. Gallagher, L.A.; McKnight, S.L.; Kuznetsova, M.S.; Pesci, E.C.; Manoil, C. Functions required for extracellular quinolone signaling by Pseudomonas aeruginosa. J. Bacteriol. 2002, 184, 6472-6480. [CrossRef] [PubMed]

117. Lépine, F.; Déziel, E.; Milot, S.; Rahme, L.G. A stable isotope dilution assay for the quantification of the Pseudomonas quinolone signal in Pseudomonas aeruginosa cultures. Biochim. Biophys. Acta 2003, 1622, 36-41. [CrossRef]

118. Déziel, E.; Lépine, F.; Milot, S.; He, J.; Mindrinos, M.N.; Tompkins, R.G.; Rahme, L.G. Analysis of Pseudomonas aeruginosa 4-hydroxy-2-alkylquinolines (HAQs) reveals a role for 4-hydroxy-2-heptylquinoline in cell-to-cell communication. Proc. Natl. Acad. Sci. USA 2004, 101, 1339-1344. [CrossRef]

119. D'Argenio, D.A.; Wu, M.; Hoffman, L.R.; Kulasekara, H.D.; Déziel, E.; Smith, E.E.; Nguyen, H.; Ernst, R.K.; Larson Freeman, T.J.; Spencer, D.H.; et al. Growth phenotypes of Pseudomonas aeruginosa lasR mutants adapted to the airways of cystic fibrosis patients. Mol. Microbiol. 2007, 64, 512-533. [CrossRef] [PubMed]

120. Schertzer, J.W.; Boulette, M.L.; Whiteley, M. More than a signal: Non-signaling properties of quorum sensing molecules. Trends Microbiol. 2009, 17, 189-195. [CrossRef]

121. Williams, P.; Cámara, M. Quorum sensing and environmental adaptation in Pseudomonas aeruginosa: A tale of regulatory networks and multifunctional signal molecules. Curr. Opin. Microbiol. 2009, 12, 182-191. [CrossRef]

122. Wade, D.S.; Calfee, M.W.; Rocha, E.R.; Ling, E.A.; Engstrom, E.; Coleman, J.P.; Pesci, E.C. Regulation of Pseudomonas quinolone signal synthesis in Pseudomonas aeruginosa. J. Bacteriol. 2005, 187, 4372-4380. [CrossRef] [PubMed]

123. Gonzalez, N.; Heeb, S.; Valverde, C.; Kay, E.; Reimmann, C.; Junier, T.; Haas, D. Genome-wide search reveals a novel GacAregulated small RNA in Pseudomonas species. BMC Genom. 2008, 9, 167. [CrossRef] [PubMed]

124. Lu, P.; Wang, Y.; Zhang, Y.; Hu, Y.; Thompson, K.M.; Chen, S. RpoS-dependent sRNA RgsA regulates Fis and AcpP in Pseudomonas aeruginosa. Mol. Microbiol. 2016, 102, 244-259. [CrossRef] [PubMed]

125. Sonnleitner, E.; González, N.; Haas, D. Small RNAs of Pseudomonas spp. In Pseudomonas; Ramos, J., Filloux, A., Eds.; Springer: Dordrecht, The Netherlands, 2010; pp. 3-28, ISBN 978-90-481-3909-5. 
126. Park, S.H.; Butcher, B.G.; Anderson, Z.; Pellegrini, N.; Bao, Z.; D’Amico, K.; Filiatrault, M.J. Analysis of the small RNA P16/RgsA in the plant pathogen Pseudomonas syringae pv. tomato strain DC3000. Microbiology 2013, 159, 296-306. [CrossRef]

127. Koch, C.; Vandekerckhove, J.; Kahmann, R. Escherichia coli host factor for site-specific DNA inversion: Cloning and characterization of the fis gene. Proc. Natl. Acad. Sci. USA 1988, 85, 4237-4241. [CrossRef] [PubMed]

128. Schneider, R.; Lurz, R.; Lüder, G.; Tolksdorf, C.; Travers, A.; Muskhelishvili, G. An architectural role of the Escherichia coli chromatin protein FIS in organising DNA. Nucleic Acids Res. 2001, 29, 5107-5114. [CrossRef]

129. Deng, W.; Marshall, N.C.; Rowland, J.L.; McCoy, J.M.; Worrall, L.J.; Santos, A.S.; Strynadka, N.C.J.; Finlay, B.B. Assembly, structure, function and regulation of type III secretion systems. Nat. Rev. Microbiol. 2017, 15, 323-337. [CrossRef]

130. Long, Y.; Fu, W.; Wang, S.; Deng, X.; Jin, Y.; Bai, F.; Cheng, Z.; Wu, W. Fis contributes to resistance of Pseudomonas aeruginosa to ciprofloxacin by regulating pyocin synthesis. J. Bacteriol. 2020, 202, e00064-20. [CrossRef]

131. Tata, M.; Amman, F.; Pawar, V.; Wolfinger, M.T.; Weiss, S.; Häussler, S.; Bläsi, U. The anaerobically induced sRNA PaiI affects denitrification in Pseudomonas aeruginosa PA14. Front. Microbiol. 2017, 8, 2312. [CrossRef]

132. Schreiber, K.; Krieger, R.; Benkert, B.; Eschbach, M.; Arai, H.; Schobert, M.; Jahn, D. The anaerobic regulatory network required for Pseudomonas aeruginosa nitrate respiration. J. Bacteriol. 2007, 189, 4310-4314. [CrossRef]

133. Wenner, N.; Maes, A.; Cotado-Sampayo, M.; Lapouge, K. NrsZ: A novel, processed, nitrogen-dependent, small non-coding RNA that regulates Pseudomonas aeruginosa PAO1 virulence. Environ. Microbiol. 2014, 16, 1053-1068. [CrossRef]

134. Papenfort, K.; Said, N.; Welsink, T.; Lucchini, S.; Hinton, J.C.D.; Vogel, J. Specific and pleiotropic patterns of mRNA regulation by ArcZ, a conserved, Hfq-dependent small RNA. Mol. Microbiol. 2009, 74, 139-158. [CrossRef]

135. Davis, B.M.; Waldor, M.K. RNase E-dependent processing stabilizes MicX, a Vibrio cholerae sRNA. Mol. Microbiol. 2007, 65, 373-385. [CrossRef]

136. Caiazza, N.C.; Shanks, R.M.Q.; O’Toole, G.A. Rhamnolipids modulate swarming motility patterns of Pseudomonas aeruginosa. J. Bacteriol. 2005, 187, 7351-7361. [CrossRef] [PubMed]

137. Sonnleitner, E.; Gonzalez, N.; Sorger-Domenigg, T.; Heeb, S.; Richter, A.S.; Backofen, R.; Williams, P.; Huttenhofer, A.; Haas, D.; Blasi, U. The small RNA PhrS stimulates synthesis of the Pseudomonas aeruginosa quinolone signal. Mol. Microbiol. 2011, 80, 868-885. [CrossRef] [PubMed]

138. Déziel, E.; Gopalan, S.; Tampakaki, A.P.; Lépine, F.; Padfield, K.E.; Saucier, M.; Xiao, G.; Rahme, L.G. The contribution of MvfR to Pseudomonas aeruginosa pathogenesis and quorum sensing circuitry regulation: Multiple quorum sensing-regulated genes are modulated without affecting lasRI, rhlRI or the production of N-acyl-L-homoserine lactones. Mol. Microbiol. 2005, 55, 998-1014. [CrossRef] [PubMed]

139. Romero, M.; Silistre, H.; Lovelock, L.; Wright, V.J.; Chan, K.-G.; Hong, K.-W.; Williams, P.; Camara, M.; Heeb, S. Genome-wide mapping of the RNA targets of the Pseudomonas aeruginosa riboregulatory protein RsmN. Nucleic Acids Res. 2018, 46, 6823-6840. [CrossRef] [PubMed]

140. Fernandez, L.; Breidenstein, E.B.M.; Taylor, P.K.; Bains, M.; De La Fuente-Nunez, C.; Fang, Y.; Foster, L.J.; Hancock, R.E.W. Interconnection of post-transcriptional regulation: The RNA-binding protein Hfq is a novel target of the Lon protease in Pseudomonas aeruginosa. Sci. Rep. 2016, 6, 26811. [CrossRef]

141. Lin, P.; Pu, Q.; Wu, Q.; Zhou, C.; Wang, B.; Schettler, J.; Wang, Z.; Qin, S.; Gao, P.; Li, R.; et al. High-throughput screen reveals sRNAs regulating crRNA biogenesis by targeting CRISPR leader to repress Rho termination. Nat. Commun. 2019, $10,3728$. [CrossRef]

142. Kambara, T.K.; Ramsey, K.M.; Dove, S.L. Pervasive targeting of nascent transcripts by Hfq. Cell Rep. 2018, $23,1543-1552$. [CrossRef]

143. Gebhardt, M.J.; Kambara, T.K.; Ramsey, K.M.; Dove, S.L. Widespread targeting of nascent transcripts by RsmA in Pseudomonas aeruginosa. Proc. Natl. Acad. Sci. USA 2020, 117, 10520-10529. [CrossRef]

144. Sun, X.; Zhulin, I.; Wartell, R.M. Predicted structure and phyletic distribution of the RNA-binding protein Hfq. Nucleic Acids Res. 2002, 30, 3662-3671. [CrossRef]

145. Scofield, D.G.; Lynch, M. Evolutionary diversification of the Sm family of RNA-associated proteins. Mol. Biol. Evol. 2008, 25, 2255-2267. [CrossRef]

146. MacGregor, C.H.; Wolff, J.A.; Arora, S.K.; Phibbs, P.V.J. Cloning of a catabolite repression control (crc) gene from Pseudomonas aeruginosa, expression of the gene in Escherichia coli, and identification of the gene product in Pseudomonas aeruginosa. J. Bacteriol. 1991, 173, 7204-7212. [CrossRef] [PubMed]

147. Sonnleitner, E.; Wulf, A.; Campagne, S.; Pei, X.-Y.; Wolfinger, M.T.; Forlani, G.; Prindl, K.; Abdou, L.; Resch, A.; Allain, F.H.-T.; et al. Interplay between the catabolite repression control protein Crc, Hfq and RNA in Hfq-dependent translational regulation in Pseudomonas aeruginosa. Nucleic Acids Res. 2018, 46, 1470-1485. [CrossRef] [PubMed]

148. Pei, X.Y.; Dendooven, T.; Sonnleitner, E.; Chen, S.; Bläsi, U.; Luisi, B.F. Architectural principles for Hfq/Crc-mediated regulation of gene expression. Elife 2019, 8, e43158. [CrossRef] [PubMed]

149. Sonnleitner, E.; Hagens, S.; Rosenau, F.; Wilhelm, S.; Habel, A.; Jäger, K.-E.; Bläsi, U. Reduced virulence of a $h f q$ mutant of Pseudomonas aeruginosa O1. Microb. Pathog. 2003, 35, 217-228. [CrossRef]

150. Sonnleitner, E.; Schuster, M.; Sorger-Domenigg, T.; Greenberg, E.P.; Blasi, U.; Bläsi, U. Hfq-dependent alterations of the transcriptome profile and effects on quorum sensing in Pseudomonas aeruginosa. Mol. Microbiol. 2006, 59, 1542-1558. [CrossRef] [PubMed] 
151. Yang, N.; Ding, S.; Chen, F.; Zhang, X.; Xia, Y.; Di, H.; Cao, Q.; Deng, X.; Wu, M.; Wong, C.C.L.; et al. The Crc protein participates in down-regulation of the Lon gene to promote rhamnolipid production and rhl quorum sensing in Pseudomonas aeruginosa. Mol. Microbiol. 2015, 96, 526-547. [CrossRef]

152. Pusic, P.; Sonnleitner, E.; Krennmayr, B.; Heitzinger, D.A.; Wolfinger, M.T.; Resch, A.; Bläsi, U. Harnessing metabolic regulation to increase Hfq-dependent antibiotic susceptibility in Pseudomonas aeruginosa. Front. Microbiol. 2018, 9, 2709. [CrossRef]

153. Zheng, A.; Panja, S.; Woodson, S.A. Arginine patch predicts the RNA annealing activity of Hfq from Gram-negative and Gram-positive bacteria. J. Mol. Biol. 2016, 428, 2259-2264. [CrossRef]

154. Møller, T.; Franch, T.; Højrup, P.; Keene, D.R.; Bächinger, H.P.; Brennan, R.G.; Valentin-Hansen, P. Hfq: A bacterial Sm-like protein that mediates RNA-RNA interaction. Mol. Cell 2002, 9, 23-30. [CrossRef]

155. Schumacher, M.A.; Pearson, R.F.; Møller, T.; Valentin-Hansen, P.; Brennan, R.G. Structures of the pleiotropic translational regulator Hfq and an Hfq-RNA complex: A bacterial Sm-like protein. EMBO J. 2002, 21, 3546-3556. [CrossRef]

156. Mikulecky, P.J.; Kaw, M.K.; Brescia, C.C.; Takach, J.C.; Sledjeski, D.D.; Feig, A.L. Escherichia coli Hfq has distinct interaction surfaces for DsrA, rpoS and poly(A) RNAs. Nat. Struct. Mol. Biol. 2004, 11, 1206-1214. [CrossRef] [PubMed]

157. de Ribeiro, E.A.J.; Beich-Frandsen, M.; Konarev, P.V.; Shang, W.; Vecerek, B.; Kontaxis, G.; Hämmerle, H.; Peterlik, H.; Svergun, D.I.; Bläsi, U.; et al. Structural flexibility of RNA as molecular basis for Hfq chaperone function. Nucleic Acids Res. 2012, 40, 8072-8084. [CrossRef] [PubMed]

158. Otaka, H.; Ishikawa, H.; Morita, T.; Aiba, H. PolyU tail of rho-independent terminator of bacterial small RNAs is essential for Hfq action. Proc. Natl. Acad. Sci. USA 2011, 108, 13059-13064. [CrossRef] [PubMed]

159. Sauer, E.; Weichenrieder, O. Structural basis for RNA 3'-end recognition by Hfq. Proc. Natl. Acad. Sci. USA 2011, 108, 13065-13070. [CrossRef]

160. Ishikawa, H.; Otaka, H.; Maki, K.; Morita, T.; Aiba, H. The functional Hfq-binding module of bacterial sRNAs consists of a double or single hairpin preceded by a U-rich sequence and followed by a 3' poly(U) tail. RNA 2012, 18, 1062-1074. [CrossRef]

161. Sauer, E.; Schmidt, S.; Weichenrieder, O. Small RNA binding to the lateral surface of Hfq hexamers and structural rearrangements upon mRNA target recognition. Proc. Natl. Acad. Sci. USA 2012, 109, 9396-9401. [CrossRef]

162. Panja, S.; Schu, D.J.; Woodson, S.A. Conserved arginines on the rim of Hfq catalyze base pair formation and exchange. Nucleic Acids Res. 2013, 41, 7536-7546. [CrossRef] [PubMed]

163. Peng, Y.; Curtis, J.E.; Fang, X.; Woodson, S.A. Structural model of an mRNA in complex with the bacterial chaperone Hfq. Proc. Natl. Acad. Sci. USA 2014, 111, 17134-17139. [CrossRef]

164. Schu, D.J.; Zhang, A.; Gottesman, S.; Storz, G. Alternative Hfq-sRNA interaction modes dictate alternative mRNA recognition. EMBO J. 2015, 34, 2557-2573. [CrossRef]

165. Link, T.M.; Valentin-Hansen, P.; Brennan, R.G. Structure of Escherichia coli Hfq bound to polyriboadenylate RNA. Proc. Natl. Acad. Sci. USA 2009, 106, 19292-19297. [CrossRef]

166. Murina, V.; Lekontseva, N.; Nikulin, A. Hfq binds ribonucleotides in three different RNA-binding sites. Acta Crystallogr. D Biol. Crystallogr. 2013, 69, 1504-1513. [CrossRef]

167. Robinson, K.E.; Orans, J.; Kovach, A.R.; Link, T.M.; Brennan, R.G. Mapping Hfq-RNA interaction surfaces using tryptophan fluorescence quenching. Nucleic Acids Res. 2014, 42, 2736-2749. [CrossRef]

168. Zhang, A.; Schu, D.J.; Tjaden, B.C.; Storz, G.; Gottesman, S. Mutations in interaction surfaces differentially impact E. coli Hfq association with small RNAs and their mRNA targets. J. Mol. Biol. 2013, 425, 3678-3697. [CrossRef]

169. Wang, L.; Wang, W.; Li, F.; Zhang, J.; Wu, J.; Gong, Q.; Shi, Y. Structural insights into the recognition of the internal A-rich linker from OxyS sRNA by Escherichia coli Hfq. Nucleic Acids Res. 2015, 43, 2400-2411. [CrossRef]

170. Sonnleitner, E.; Valentini, M.; Wenner, N.; Haichar, F.E.Z.; Haas, D.; Lapouge, K. Novel targets of the CbrAB/Crc carbon catabolite control system revealed by transcript abundance in Pseudomonas aeruginosa. PLoS ONE 2012, 7, e44637. [CrossRef]

171. Linares, J.F.; Moreno, R.; Fajardo, A.; Martínez-Solano, L.; Escalante, R.; Rojo, F.; Martínez, J.L. The global regulator Crc modulates metabolism, susceptibility to antibiotics and virulence in Pseudomonas aeruginosa. Environ. Microbiol. 2010, 12, 3196-3212. [CrossRef]

172. Corona, F.; Reales-Calderón, J.A.; Gil, C.; Martínez, J.L. The development of a new parameter for tracking post-transcriptional regulation allows the detailed map of the Pseudomonas aeruginosa Crc regulon. Sci. Rep. 2018, 8, 16793. [CrossRef]

173. Romeo, T.; Vakulskas, C.A.; Babitzke, P. Post-transcriptional regulation on a global scale: Form and function of Csr/Rsm systems. Environ. Microbiol. 2013, 15, 313-324. [CrossRef]

174. Vakulskas, C.A.; Potts, A.H.; Babitzke, P.; Ahmer, B.M.M.; Romeo, T. Regulation of bacterial virulence by Csr (Rsm) systems. Microbiol. Mol. Biol. Rev. 2015, 79, 193-224. [CrossRef]

175. Holmqvist, E.; Wright, P.R.; Li, L.; Bischler, T.; Barquist, L.; Reinhardt, R.; Backofen, R.; Vogel, J. Global RNA recognition patterns of post-transcriptional regulators Hfq and CsrA revealed by UV crosslinking in vivo. EMBO J. 2016, 35, 991-1011. [CrossRef]

176. Kusmierek, M.; Dersch, P. Regulation of host-pathogen interactions via the post-transcriptional Csr/Rsm system. Curr. Opin. Microbiol. 2018, 41, 58-67. [CrossRef] [PubMed]

177. Farrow, J.M., 3rd; Wells, G.; Palethorpe, S.; Adams, M.D.; Pesci, E.C. CsrA supports both environmental persistence and host-associated growth of Acinetobacter baumannii. Infect. Immun. 2020, 88, e00259-20. [CrossRef]

178. Butz, H.A.; Mey, A.R.; Ciosek, A.L.; Crofts, A.A.; Davies, B.W.; Payne, S.M. Regulatory effects of CsrA in Vibrio cholerae. MBio 2021, 12, e03380-20. [CrossRef] [PubMed] 
179. Burrowes, E.; Baysse, C.; Adams, C.; O'Gara, F. Influence of the regulatory protein RsmA on cellular functions in Pseudomonas aeruginosa PAO1, as revealed by transcriptome analysis. Microbiology 2006, 152, 405-418. [CrossRef]

180. Dubey, A.K.; Baker, C.S.; Romeo, T.; Babitzke, P. RNA sequence and secondary structure participate in high-affinity CsrA-RNA interaction. RNA 2005, 11, 1579-1587. [CrossRef]

181. Schubert, M.; Lapouge, K.; Duss, O.; Oberstrass, F.C.; Jelesarov, I.; Haas, D.; Allain, F.H.-T. Molecular basis of messenger RNA recognition by the specific bacterial repressing clamp RsmA/CsrA. Nat. Struct. Mol. Biol. 2007, 14, 807-813. [CrossRef]

182. Marden, J.N.; Diaz, M.R.; Walton, W.G.; Gode, C.J.; Betts, L.; Urbanowski, M.L.; Redinbo, M.R.; Yahr, T.L.; Wolfgang, M.C. An unusual CsrA family member operates in series with RsmA to amplify posttranscriptional responses in Pseudomonas aeruginosa. Proc. Natl. Acad. Sci. USA 2013, 110, 15055-15060. [CrossRef]

183. Schulmeyer, K.H.; Diaz, M.R.; Bair, T.B.; Sanders, W.; Gode, C.J.; Laederach, A.; Wolfgang, M.C.; Yahr, T.L. Primary and secondary sequence structure requirements for recognition and discrimination of target RNAs by Pseudomonas aeruginosa RsmA and RsmF. J. Bacteriol. 2016, 198, 2458-2469. [CrossRef]

184. Chihara, K.; Barquist, L.; Takasugi, K.; Noda, N.; Tsuneda, S. Global identification of RsmA/N binding sites in Pseudomonas aeruginosa by in vivo UV CLIP-seq. RNA Biol. 2021, 1-16. [CrossRef]

185. Brencic, A.; Lory, S. Determination of the regulon and identification of novel mRNA targets of Pseudomonas aeruginosa RsmA. Mol. Microbiol. 2009, 72, 612-632. [CrossRef]

186. Heurlier, K.; Williams, F.; Heeb, S.; Dormond, C.; Pessi, G.; Singer, D.; Cámara, M.; Williams, P.; Haas, D. Positive control of swarming, rhamnolipid synthesis, and lipase production by the posttranscriptional RsmA/RsmZ system in Pseudomonas aeruginosa PAO1. J. Bacteriol. 2004, 186, 2936-2945. [CrossRef]

187. Frangipani, E.; Visaggio, D.; Heeb, S.; Kaever, V.; Cámara, M.; Visca, P.; Imperi, F. The Gac/Rsm and cyclic-di-GMP signalling networks coordinately regulate iron uptake in Pseudomonas aeruginosa. Environ. Microbiol. 2014, 16, 676-688. [CrossRef]

188. Sonnleitner, E.; Romeo, A.; Bläsi, U. Small regulatory RNAs in Pseudomonas aeruginosa. RNA Biol. 2012, 9, 364-371. [CrossRef] [PubMed]

189. La Rosa, R.; Behrends, V.; Williams, H.D.; Bundy, J.G.; Rojo, F. Influence of the Crc regulator on the hierarchical use of carbon sources from a complete medium in Pseudomonas. Environ. Microbiol. 2016, 18, 807-818. [CrossRef] [PubMed]

190. Molina, L.; La Rosa, R.; Nogales, J.; Rojo, F. Influence of the Crc global regulator on substrate uptake rates and the distribution of metabolic fluxes in Pseudomonas putida KT2440 growing in a complete medium. Environ. Microbiol. 2019, 21, 4446-4459. [CrossRef] [PubMed]

191. Hester, K.L.; Lehman, J.; Najar, F.; Song, L.; Roe, B.A.; MacGregor, C.H.; Hager, P.W.; Phibbs, P.V.J.; Sokatch, J.R. Crc is involved in catabolite repression control of the $b k d$ operons of Pseudomonas putida and Pseudomonas aeruginosa. J. Bacteriol. 2000, 182, 1144-1149. [CrossRef]

192. Hester, K.L.; Madhusudhan, K.T.; Sokatch, J.R. Catabolite repression control by crc in 2xYT medium is mediated by posttranscriptional regulation of $b k d R$ expression in Pseudomonas putida. J. Bacteriol. 2000, 182, 1150-1153. [CrossRef]

193. Sonnleitner, E.; Abdou, L.; Haas, D. Small RNA as global regulator of carbon catabolite repression in Pseudomonas aeruginosa. Proc. Natl. Acad. Sci. USA 2009, 106, 21866-21871. [CrossRef]

194. Huang, J.; Sonnleitner, E.; Ren, B.; Xu, Y.; Haas, D. Catabolite repression control of pyocyanin biosynthesis at an intersection of primary and secondary metabolism in Pseudomonas aeruginosa. Appl. Environ. Microbiol. 2012, 78, 5016-5020. [CrossRef]

195. Reales-Calderón, J.A.; Corona, F.; Monteoliva, L.; Gil, C.; Martínez, J.L. Quantitative proteomics unravels that the posttranscriptional regulator $\mathrm{Crc}$ modulates the generation of vesicles and secreted virulence determinants of Pseudomonas aeruginosa. J. Proteomics 2015, 127, 352-364. [CrossRef]

196. La Rosa, R.; Nogales, J.; Rojo, F. The Crc/CrcZ-CrcY global regulatory system helps the integration of gluconeogenic and glycolytic metabolism in Pseudomonas putida. Environ. Microbiol. 2015, 17, 3362-3378. [CrossRef]

197. Moreno, R.; Hernández-Arranz, S.; La Rosa, R.; Yuste, L.; Madhushani, A.; Shingler, V.; Rojo, F. The Crc and Hfq proteins of Pseudomonas putida cooperate in catabolite repression and formation of ribonucleic acid complexes with specific target motifs. Environ. Microbiol. 2015, 17, 105-118. [CrossRef]

198. Malecka, E.M.; Bassani, F.; Dendooven, T.; Sonnleitner, E.; Rozner, M.; Albanese, T.G.; Resch, A.; Luisi, B.; Woodson, S.; Bläsi, U. Stabilization of Hfq-mediated translational repression by the co-repressor Crc in Pseudomonas aeruginosa. Nucleic Acids Res. 2021, 49, 7075-7087. [CrossRef]

199. Pusic, P.; Tata, M.; Wolfinger, M.T.; Sonnleitner, E.; Häussler, S.; Bläsi, U. Cross-regulation by CrcZ RNA controls anoxic biofilm formation in Pseudomonas aeruginosa. Sci. Rep. 2016, 6, 39621. [CrossRef]

200. O'Toole, G.A.; Gibbs, K.A.; Hager, P.W.; Phibbs, P.V.J.; Kolter, R. The global carbon metabolism regulator Crc is a component of a signal transduction pathway required for biofilm development by Pseudomonas aeruginosa. J. Bacteriol. 2000, 182, 425-431. [CrossRef]

201. Zhang, L.; Gao, Q.; Chen, W.; Qin, H.; Hengzhuang, W.; Chen, Y.; Yang, L.; Zhang, G. Regulation of PQS quorum sensing via catabolite repression control in Pseudomonas aeruginosa. Microbiology 2013, 159, 1931-1936. [CrossRef] [PubMed]

202. Moreno, R.; Fonseca, P.; Rojo, F. Two small RNAs, CrcY and CrcZ, act in concert to sequester the Crc global regulator in Pseudomonas putida, modulating catabolite repression. Mol. Microbiol. 2012, 83, 24-40. [CrossRef] 
203. Filiatrault, M.J.; Stodghill, P.V.; Bronstein, P.A.; Moll, S.; Lindeberg, M.; Grills, G.; Schweitzer, P.; Wang, W.; Schroth, G.P.; Luo, S.; et al. Transcriptome analysis of Pseudomonas syringae identifies new genes, noncoding RNAs, and antisense activity. J. Bacteriol. 2010, 192, 2359-2372. [CrossRef]

204. Filiatrault, M.J.; Stodghill, P.V.; Wilson, J.; Butcher, B.G.; Chen, H.; Myers, C.R.; Cartinhour, S.W. CrcZ and CrcX regulate carbon source utilization in Pseudomonas syringae pathovar tomato strain DC3000. RNA Biol. 2013, 10, 245-255. [CrossRef]

205. Liu, Y.; Gokhale, C.S.; Rainey, P.B.; Zhang, X.-X. Unravelling the complexity and redundancy of carbon catabolic repression in Pseudomonas fluorescens SBW25. Mol. Microbiol. 2017, 105, 589-605. [CrossRef]

206. Abdou, L.; Chou, H.T.; Haas, D.; Lu, C.D. Promoter recognition and activation by the global response regulator CbrB in Pseudomonas aeruginosa. J. Bacteriol. 2011, 193, 2784-2792. [CrossRef]

207. Nishijyo, T.; Haas, D.; Itoh, Y. The CbrA-CbrB two-component regulatory system controls the utilization of multiple carbon and nitrogen sources in Pseudomonas aeruginosa. Mol. Microbiol. 2001, 40, 917-931. [CrossRef] [PubMed]

208. Li, W.; Lu, C.-D. Regulation of carbon and nitrogen utilization by CbrAB and NtrBC two-component systems in Pseudomonas aeruginosa. J. Bacteriol. 2007, 189, 5413-5420. [CrossRef]

209. Valentini, M.; García-Mauriño, S.M.; Pérez-Martínez, I.; Santero, E.; Canosa, I.; Lapouge, K. Hierarchical management of carbon sources is regulated similarly by the CbrA/B systems in Pseudomonas aeruginosa and Pseudomonas putida. Microbiology 2014, 160, 2243-2252. [CrossRef] [PubMed]

210. Romeo, T.; Gong, M.; Liu, M.Y.; Brun-Zinkernagel, A.M. Identification and molecular characterization of $c s r A$, a pleiotropic gene from Escherichia coli that affects glycogen biosynthesis, gluconeogenesis, cell size, and surface properties. J. Bacteriol. 1993, 175, 4744-4755. [CrossRef] [PubMed]

211. Hernández-Arranz, S.; Sánchez-Hevia, D.; Rojo, F.; Moreno, R. Effect of Crc and Hfq proteins on the transcription, processing, and stability of the Pseudomonas putida CrcZ sRNA. RNA 2016, 22, 1902-1917. [CrossRef]

212. Pessi, G.; Williams, F.; Hindle, Z.; Heurlier, K.; Holden, M.T.G.; Cámara, M.; Haas, D.; Williams, P. The global posttranscriptional regulator RsmA modulates production of virulence determinants $\mathrm{N}$-acylhomoserine lactones in Pseudomonas aeruginosa. J. Bacteriol. 2001, 183, 6676-6683. [CrossRef]

213. Morris, E.R.; Hall, G.; Li, C.; Heeb, S.; Kulkarni, R.V.; Lovelock, L.; Silistre, H.; Messina, M.; Cámara, M.; Emsley, J.; et al. Structural rearrangement in an RsmA/CsrA ortholog of Pseudomonas aeruginosa creates a dimeric RNA-binding protein, RsmN. Structure 2013, 21, 1659-1671. [CrossRef]

214. Romeo, T.; Gong, M. Genetic and physical mapping of the regulatory gene csrA on the Escherichia coli K-12 chromosome. J. Bacteriol. 1993, 175, 5740-5741. [CrossRef]

215. Sabnis, N.A.; Yang, H.; Romeo, T. Pleiotropic regulation of central carbohydrate metabolism in Escherichia coli via the gene csrA. J. Biol. Chem. 1995, 270, 29096-29104. [CrossRef] [PubMed]

216. Potts, A.H.; Vakulskas, C.A.; Pannuri, A.; Yakhnin, H.; Babitzke, P.; Romeo, T. Global role of the bacterial post-transcriptional regulator CsrA revealed by integrated transcriptomics. Nat. Commun. 2017, 8, 1596. [CrossRef] [PubMed]

217. Sobrero, P.M.; Valverde, C. Comparative genomics and evolutionary analysis of RNA-binding proteins of the CsrA family in the genus Pseudomonas. Front. Mol. Biosci. 2020, 7, 127. [CrossRef]

218. Janssen, K.H.; Diaz, M.R.; Golden, M.; Graham, J.W.; Sanders, W.; Wolfgang, M.C.; Yahr, T.L. Functional analyses of the RsmY and RsmZ small noncoding regulatory RNAs in Pseudomonas aeruginosa. J. Bacteriol. 2018, 200, e00736-17. [CrossRef] [PubMed]

219. Janssen, K.H.; Diaz, M.R.; Gode, C.J.; Wolfgang, M.C.; Yahr, T.L. RsmV, a small noncoding regulatory RNA in Pseudomonas aeruginosa that sequesters RsmA and RsmF from target mRNAs. J. Bacteriol. 2018, 200, e00277-18. [CrossRef]

220. Mulcahy, H.; Callaghan, J.; Grady, E.P.; Maciá, M.D.; Borrell, N.; Gómez, C.; Casey, P.G.; Hill, C.; Adams, C.; Gahan, C.G.M.; et al. Pseudomonas aeruginosa RsmA plays an important role during murine infection by influencing colonization, virulence, persistence, and pulmonary inflammation. Infect. Immun. 2008, 76, 632-638. [CrossRef]

221. Yahr, T.L.; Wolfgang, M.C. Transcriptional regulation of the Pseudomonas aeruginosa type III secretion system. Mol. Microbiol. 2006, 62, 631-640. [CrossRef]

222. Brutinel, E.D.; Vakulskas, C.A.; Brady, K.M.; Yahr, T.L. Characterization of ExsA and of ExsA-dependent promoters required for expression of the Pseudomonas aeruginosa type III secretion system. Mol. Microbiol. 2008, 68, 657-671. [CrossRef]

223. Intile, P.J.; Diaz, M.R.; Urbanowski, M.L.; Wolfgang, M.C.; Yahr, T.L. The AlgZR two-component system recalibrates the RsmAYZ posttranscriptional regulatory system to inhibit expression of the Pseudomonas aeruginosa type III secretion system. J. Bacteriol. 2014, 196, 357-366. [CrossRef]

224. de Bentzmann, S.; Giraud, C.; Bernard, C.S.; Calderon, V.; Ewald, F.; Plésiat, P.; Nguyen, C.; Grunwald, D.; Attree, I.; Jeannot, K.; et al. Unique biofilm signature, drug susceptibility and decreased virulence in Drosophila through the Pseudomonas aeruginosa two-component system PprAB. PLoS Pathog. 2012, 8, e1003052. [CrossRef]

225. Baynham, P.J.; Ramsey, D.M.; Gvozdyev, B.V.; Cordonnier, E.M.; Wozniak, D.J. The Pseudomonas aeruginosa ribbon-helix-helix DNA-binding protein AlgZ (AmrZ) controls twitching motility and biogenesis of type IV pili. J. Bacteriol. 2006, 188, 132-140. [CrossRef] [PubMed]

226. Xu, A.; Zhang, M.; Du, W.; Wang, D.; Ma, L.Z. A molecular mechanism for how sigma factor AlgT and transcriptional regulator AmrZ inhibit twitching motility in Pseudomonas aeruginosa. Environ. Microbiol. 2021, 23, 572-587. [CrossRef] [PubMed] 
227. Allsopp, L.P.; Wood, T.E.; Howard, S.A.; Maggiorelli, F.; Nolan, L.M.; Wettstadt, S.; Filloux, A. RsmA and AmrZ orchestrate the assembly of all three type VI secretion systems in Pseudomonas aeruginosa. Proc. Natl. Acad. Sci. USA 2017, 114, 7707-7712. [CrossRef] [PubMed]

228. Baynham, P.J.; Wozniak, D.J. Identification and characterization of AlgZ, an AlgT-dependent DNA-binding protein required for Pseudomonas aeruginosa algD transcription. Mol. Microbiol. 1996, 22, 97-108. [CrossRef]

229. Baynham, P.J.; Brown, A.L.; Hall, L.L.; Wozniak, D.J. Pseudomonas aeruginosa AlgZ, a ribbon-helix-helix DNA-binding protein, is essential for alginate synthesis and algD transcriptional activation. Mol. Microbiol. 1999, 33, 1069-1080. [CrossRef] [PubMed]

230. Waligora, E.A.; Ramsey, D.M.; Pryor, E.E.J.; Lu, H.; Hollis, T.; Sloan, G.P.; Deora, R.; Wozniak, D.J. AmrZ beta-sheet residues are essential for DNA binding and transcriptional control of Pseudomonas aeruginosa virulence genes. J. Bacteriol. 2010, 192, 5390-5401. [CrossRef] [PubMed]

231. Pryor, E.E.J.; Waligora, E.A.; Xu, B.; Dellos-Nolan, S.; Wozniak, D.J.; Hollis, T. The transcription factor AmrZ utilizes multiple DNA binding modes to recognize activator and repressor sequences of Pseudomonas aeruginosa virulence genes. PLoS Pathog. 2012, 8, e1002648. [CrossRef]

232. Jones, C.J.; Newsom, D.; Kelly, B.; Irie, Y.; Jennings, L.K.; Xu, B.; Limoli, D.H.; Harrison, J.J.; Parsek, M.R.; White, P.; et al. ChIP-Seq and RNA-Seq reveal an AmrZ-mediated mechanism for cyclic di-GMP synthesis and biofilm development by Pseudomonas aeruginosa. PLoS Pathog. 2014, 10, e1003984. [CrossRef]

233. Tart, A.H.; Blanks, M.J.; Wozniak, D.J. The AlgT-dependent transcriptional regulator AmrZ (AlgZ) inhibits flagellum biosynthesis in mucoid, nonmotile Pseudomonas aeruginosa cystic fibrosis isolates. J. Bacteriol. 2006, 188, 6483-6489. [CrossRef]

234. Jones, C.J.; Ryder, C.R.; Mann, E.E.; Wozniak, D.J. AmrZ modulates Pseudomonas aeruginosa biofilm architecture by directly repressing transcription of the $p s l$ operon. J. Bacteriol. 2013, 195, 1637-1644. [CrossRef]

235. Rocchetta, H.L.; Burrows, L.L.; Lam, J.S. Genetics of O-antigen biosynthesis in Pseudomonas aeruginosa. Microbiol. Mol. Biol. Rev. 1999, 63, 523-553. [CrossRef] [PubMed]

236. Cross, A.R.; Goldberg, J.B. Remodeling of O antigen in mucoid Pseudomonas aeruginosa via transcriptional repression of wzz2. MBio 2019, 10, e02914-18. [CrossRef]

237. Huang, H.; Shao, X.; Xie, Y.; Wang, T.; Zhang, Y.; Wang, X.; Deng, X. An integrated genomic regulatory network of virulencerelated transcriptional factors in Pseudomonas aeruginosa. Nat. Commun. 2019, 10, 2931. [CrossRef] [PubMed]

238. Goodman, A.L.; Kulasekara, B.; Rietsch, A.; Boyd, D.; Smith, R.S.; Lory, S. A signaling network reciprocally regulates genes associated with acute infection and chronic persistence in Pseudomonas aeruginosa. Dev. Cell 2004, 7, 745-754. [CrossRef]

239. Furukawa, S.; Kuchma, S.L.; O'Toole, G.A. Keeping their options open: Acute versus persistent infections. J. Bacteriol. 2006, 188, 1211-1217. [CrossRef]

240. Wagner, V.E.; Iglewski, B.H. P. aeruginosa biofilms in CF infection. Clin. Rev. Allergy Immunol. 2008, 35, 124-134. [CrossRef] [PubMed]

241. Franklin, M.J.; Nivens, D.E.; Weadge, J.T.; Howell, P.L. Biosynthesis of the Pseudomonas aeruginosa extracellular polysaccharides, alginate, Pel, and Psl. Front. Microbiol. 2011, 2, 167. [CrossRef]

242. Silverman, J.M.; Brunet, Y.R.; Cascales, E.; Mougous, J.D. Structure and regulation of the type VI secretion system. Annu. Rev. Microbiol. 2012, 66, 453-472. [CrossRef]

243. Irie, Y.; Starkey, M.; Edwards, A.N.; Wozniak, D.J.; Romeo, T.; Parsek, M.R. Pseudomonas aeruginosa biofilm matrix polysaccharide Psl is regulated transcriptionally by RpoS and post-transcriptionally by RsmA. Mol. Microbiol. 2010, 78, 158-172. [CrossRef] [PubMed]

244. Wozniak, D.J.; Ohman, D.E. Transcriptional analysis of the Pseudomonas aeruginosa genes algR, algB, and algD reveals a hierarchy of alginate gene expression which is modulated by algT. J. Bacteriol. 1994, 176, 6007-6014. [CrossRef] [PubMed]

245. Hershberger, C.D.; Ye, R.W.; Parsek, M.R.; Xie, Z.D.; Chakrabarty, A.M. The algT (algU) gene of Pseudomonas aeruginosa, a key regulator involved in alginate biosynthesis, encodes an alternative sigma factor (sigma E). Proc. Natl. Acad. Sci. USA 1995, 92, 7941-7945. [CrossRef] [PubMed]

246. Stacey, S.D.; Pritchett, C.L. Pseudomonas aeruginosa AlgU contributes to posttranscriptional activity by increasing rsmA expression in a mucA22 Strain. J. Bacteriol. 2016, 198, 1812-1826. [CrossRef]

247. Lee, V.T.; Matewish, J.M.; Kessler, J.L.; Hyodo, M.; Hayakawa, Y.; Lory, S. A cyclic-di-GMP receptor required for bacterial exopolysaccharide production. Mol. Microbiol. 2007, 65, 1474-1484. [CrossRef]

248. Coggan, K.A.; Wolfgang, M.C. Global regulatory pathways and cross-talk control Pseudomonas aeruginosa environmental lifestyle and virulence phenotype. Curr. Issues Mol. Biol. 2012, 14, 47-70.

249. Moscoso, J.A.; Jaeger, T.; Valentini, M.; Hui, K.; Jenal, U.; Filloux, A. The diguanylate cyclase SadC is a central player in Gac/Rsm-mediated biofilm formation in Pseudomonas aeruginosa. J. Bacteriol. 2014, 196, 4081-4088. [CrossRef]

250. Colley, B.; Dederer, V.; Carnell, M.; Kjelleberg, S.; Rice, S.A.; Klebensberger, J. SiaA/D interconnects c-di-GMP and RsmA signaling to coordinate cellular aggregation of Pseudomonas aeruginosa in response to rnvironmental conditions. Front. Microbiol. 2016, 7 , 179. [CrossRef]

251. Huertas-Rosales, Ó.; Romero, M.; Heeb, S.; Espinosa-Urgel, M.; Cámara, M.; Ramos-González, M.I. The Pseudomonas putida CsrA/RsmA homologues negatively affect c-di-GMP pools and biofilm formation through the GGDEF/EAL response regulator CfcR. Environ. Microbiol. 2017, 19, 3551-3566. [CrossRef] [PubMed] 
252. Allesen-Holm, M.; Barken, K.B.; Yang, L.; Klausen, M.; Webb, J.S.; Kjelleberg, S.; Molin, S.; Givskov, M.; Tolker-Nielsen, T. A characterization of DNA release in Pseudomonas aeruginosa cultures and biofilms. Mol. Microbiol. 2006, 59, 1114-1128. [CrossRef]

253. Kay, E.; Humair, B.; Dénervaud, V.; Riedel, K.; Spahr, S.; Eberl, L.; Valverde, C.; Haas, D. Two GacA-dependent small RNAs modulate the quorum-sensing response in Pseudomonas aeruginosa. J. Bacteriol. 2006, 188, 6026-6033. [CrossRef]

254. Burrowes, E.; Abbas, A.; O'Neill, A.; Adams, C.; O'Gara, F. Characterisation of the regulatory RNA RsmB from Pseudomonas aeruginosa PAO1. Res. Microbiol. 2005, 156, 7-16. [CrossRef]

255. Valverde, C.; Heeb, S.; Keel, C.; Haas, D. RsmY, a small regulatory RNA, is required in concert with RsmZ for GacA-dependent expression of biocontrol traits in Pseudomonas fluorescens CHA0. Mol. Microbiol. 2003, 50, 1361-1379. [CrossRef] [PubMed]

256. Miller, C.L.; Romero, M.; Karna, S.L.R.; Chen, T.; Heeb, S.; Leung, K.P. RsmW, Pseudomonas aeruginosa small non-coding RsmA-binding RNA upregulated in biofilm versus planktonic growth conditions. BMC Microbiol. 2016, 16, 155. [CrossRef] [PubMed]

257. Heeb, S.; Heurlier, K.; Valverde, C.; Cámara, M.; Haas, D.; Williams, P. Post-transcriptional regulation in Pseudomonas spp. via the Gac/Rsm regulatory network. In Virulence and Gene Regulation; Ramos, J.-L., Ed.; Springer: Boston, MA, USA, 2004; pp. 239-255, ISBN 978-1-4419-9084-6.

258. Mulcahy, H.; O'Callaghan, J.; O'Grady, E.P.; Adams, C.; O'Gara, F. The posttranscriptional regulator RsmA plays a role in the interaction between Pseudomonas aeruginosa and human airway epithelial cells by positively regulating the type III secretion system. Infect. Immun. 2006, 74, 3012-3015. [CrossRef]

259. Brencic, A.; McFarland, K.A.; McManus, H.R.; Castang, S.; Mogno, I.; Dove, S.L.; Lory, S. The GacS/GacA signal transduction system of Pseudomonas aeruginosa acts exclusively through its control over the transcription of the RsmY and RsmZ regulatory small RNAs. Mol. Microbiol. 2009, 73, 434-445. [CrossRef]

260. Bordi, C.; Lamy, M.-C.; Ventre, I.; Termine, E.; Hachani, A.; Fillet, S.; Roche, B.; Bleves, S.; Méjean, V.; Lazdunski, A.; et al. Regulatory RNAs and the HptB/RetS signalling pathways fine-tune Pseudomonas aeruginosa pathogenesis. Mol. Microbiol. 2010, 76, 1427-1443. [CrossRef]

261. Li, K.; Yang, G.; Debru, A.B.; Li, P.; Zong, L.; Li, P.; Xu, T.; Wu, W.; Jin, S.; Bao, Q. SuhB regulates the motile-sessile switch in Pseudomonas aeruginosa through the Gac/Rsm pathway and c-di-GMP signaling. Front. Microbiol. 2017, 8, 1045. [CrossRef] [PubMed]

262. Petrova, O.E.; Sauer, K. The novel two-component regulatory system BfiSR regulates biofilm development by controlling the small RNA rsmZ through CafA. J. Bacteriol. 2010, 192, 5275-5288. [CrossRef]

263. Ventre, I.; Goodman, A.L.; Vallet-Gely, I.; Vasseur, P.; Soscia, C.; Molin, S.; Bleves, S.; Lazdunski, A.; Lory, S.; Filloux, A. Multiple sensors control reciprocal expression of Pseudomonas aeruginosa regulatory RNA and virulence genes. Proc. Natl. Acad. Sci. USA 2006, 103, 171-176. [CrossRef]

264. Laskowski, M.A.; Osborn, E.; Kazmierczak, B.I. A novel sensor kinase-response regulator hybrid regulates type III secretion and is required for virulence in Pseudomonas aeruginosa. Mol. Microbiol. 2004, 54, 1090-1103. [CrossRef] [PubMed]

265. Laskowski, M.A.; Kazmierczak, B.I. Mutational analysis of RetS, an unusual sensor kinase-response regulator hybrid required for Pseudomonas aeruginosa virulence. Infect. Immun. 2006, 74, 4462-4473. [CrossRef]

266. Goodman, A.L.; Merighi, M.; Hyodo, M.; Ventre, I.; Filloux, A.; Lory, S. Direct interaction between sensor kinase proteins mediates acute and chronic disease phenotypes in a bacterial pathogen. Genes Dev. 2009, 23, 249-259. [CrossRef] [PubMed]

267. Chambonnier, G.; Roux, L.; Redelberger, D.; Fadel, F.; Filloux, A.; Sivaneson, M.; de Bentzmann, S.; Bordi, C. The hybrid histidine kinase LadS forms a multicomponent signal transduction system with the GacS/GacA two-component system in Pseudomonas aeruginosa. PLoS Genet. 2016, 12, e1006032. [CrossRef] [PubMed]

268. Bhagirath, A.Y.; Pydi, S.P.; Li, Y.; Lin, C.; Kong, W.; Chelikani, P.; Duan, K. Characterization of the direct interaction between hybrid sensor kinases PA1611 and RetS that controls biofilm formation and the type III secretion system in Pseudomonas aeruginosa. ACS Infect. Dis. 2017, 3, 162-175. [CrossRef]

269. Jean-Pierre, F.; Tremblay, J.; Déziel, E. Broth versus surface-grown cells: Differential regulation of RsmY/Z small RNAs in Pseudomonas aeruginosa by the Gac/HptB system. Front. Microbiol. 2017, 7, 2168. [CrossRef]

270. Bouillet, S.; Ba, M.; Houot, L.; Iobbi-Nivol, C.; Bordi, C. Connected partner-switches control the life style of Pseudomonas aeruginosa through RpoS regulation. Sci. Rep. 2019, 9, 6496. [CrossRef]

271. Li, K.; Xu, C.; Jin, Y.; Sun, Z.; Liu, C.; Shi, J.; Chen, G.; Chen, R.; Jin, S.; Wu, W. SuhB is a regulator of multiple virulence genes and essential for pathogenesis of Pseudomonas aeruginosa. MBio 2013, 4, e00419-13. [CrossRef]

272. O'Callaghan, J.; Reen, F.J.; Adams, C.; O'Gara, F. Low oxygen induces the type III secretion system in Pseudomonas aeruginosa via modulation of the small RNAs $r s m Z$ and $r s m Y$. Microbiology 2011, 157, 3417-3428. [CrossRef] [PubMed]

273. Chakravarty, S.; Melton, C.N.; Bailin, A.; Yahr, T.L.; Anderson, G.G. Pseudomonas aeruginosa magnesium transporter MgtE inhibits type III secretion system gene expression by stimulating rsm YZ transcription. J. Bacteriol. 2017, 199, e00268-17. [CrossRef]

274. Janssen, K.H.; Corley, J.M.; Djapgne, L.; Cribbs, J.T.; Voelker, D.; Slusher, Z.; Nordell, R.; Regulski, E.E.; Kazmierczak, B.I.; McMackin, E.W.; et al. Hfq and sRNA 179 inhibit expression of the Pseudomonas aeruginosa cAMP-Vfr and type III secretion regulons. MBio 2020, 11, e00363-20. [CrossRef]

275. Liu, W.; Li, M.; Jiao, L.; Wang, P.; Yan, Y. PmrA/PmrB two-component system regulation of lipA expression in Pseudomonas aeruginosa PAO1. Front. Microbiol. 2018, 8, 2690. [CrossRef] [PubMed] 
276. Castang, S.; McManus, H.R.; Turner, K.H.; Dove, S.L. H-NS family members function coordinately in an opportunistic pathogen. Proc. Natl. Acad. Sci. USA 2008, 105, 18947-18952. [CrossRef] [PubMed]

277. Wang, C.; Ye, F.; Kumar, V.; Gao, Y.-G.; Zhang, L.-H. BswR controls bacterial motility and biofilm formation in Pseudomonas aeruginosa through modulation of the small RNA rsmZ. Nucleic Acids Res. 2014, 42, 4563-4576. [CrossRef] [PubMed]

278. Reimmann, C.; Valverde, C.; Kay, E.; Haas, D. Posttranscriptional repression of GacS/GacA-controlled genes by the RNA-binding protein RsmE acting together with RsmA in the biocontrol strain Pseudomonas fluorescens CHA0. J. Bacteriol. 2005, 187, $276-285$. [CrossRef]

279. Sorger-Domenigg, T.; Sonnleitner, E.; Kaberdin, V.R.; Bläsi, U. Distinct and overlapping binding sites of Pseudomonas aeruginosa Hfq and RsmA proteins on the non-coding RNA RsmY. Biochem. Biophys. Res. Commun. 2007, 352, 769-773. [CrossRef] [PubMed]

280. Rosenzweig, J.A.; Chopra, A.K. The exoribonuclease polynucleotide phosphorylase influences the virulence and stress responses of yersiniae and many other pathogens. Front. Cell. Infect. Microbiol. 2013, 3, 81. [CrossRef]

281. Chen, R.; Weng, Y.; Zhu, F.; Jin, Y.; Liu, C.; Pan, X.; Xia, B.; Cheng, Z.; Jin, S.; Wu, W. Polynucleotide phosphorylase regulates multiple virulence factors and the stabilities of small RNAs RsmY/Z in Pseudomonas aeruginosa. Front. Microbiol. $2016,7,247$. [CrossRef] [PubMed]

282. Smirnov, A.; Förstner, K.U.; Holmqvist, E.; Otto, A.; Günster, R.; Becher, D.; Reinhardt, R.; Vogel, J. Grad-seq guides the discovery of ProQ as a major small RNA-binding protein. Proc. Natl. Acad. Sci. USA 2016, 113, 11591-11596. [CrossRef]

283. Smirnov, A.; Schneider, C.; Hör, J.; Vogel, J. Discovery of new RNA classes and global RNA-binding proteins. Curr. Opin. Microbiol. 2017, 39, 152-160. [CrossRef] [PubMed]

284. Gerovac, M.; El Mouali, Y.; Kuper, J.; Kisker, C.; Barquist, L.; Vogel, J. Global discovery of bacterial RNA-binding proteins by RNase-sensitive gradient profiles reports a new FinO domain protein. RNA 2020, 26, 1448-1463. [CrossRef] [PubMed]

285. Hör, J.; Garriss, G.; Di Giorgio, S.; Hack, L.-M.; Vanselow, J.T.; Förstner, K.U.; Schlosser, A.; Henriques-Normark, B.; Vogel, J. Grad-seq in a Gram-positive bacterium reveals exonucleolytic sRNA activation in competence control. EMBO J. 2020, 39 , e103852. [CrossRef] [PubMed]

286. Hör, J.; Vogel, J. Analysis of the RNA and protein complexome by Grad-seq. Methods Mol. Biol. 2021, 2300, 183-201. [CrossRef]

287. Gerovac, M.; Wicke, L.; Chihara, K.; Schneider, C.; Lavigne, R.; Vogel, J. A Grad-seq view of RNA and protein complexes in Pseudomonas aeruginosa under standard and bacteriophage predation conditions. MBio 2021, 12, e03454-20. [CrossRef] [PubMed]

288. Gerovac, M.; Vogel, J.; Smirnov, A. The world of stable ribonucleoproteins and its mapping with Grad-seq and related approaches. Front. Mol. Biosci. 2021, 8, 661448. [CrossRef]

289. Tacconelli, E.; Carrara, E.; Savoldi, A.; Harbarth, S.; Mendelson, M.; Monnet, D.L.; Pulcini, C.; Kahlmeter, G.; Kluytmans, J.; Carmeli, Y.; et al. Discovery, research, and development of new antibiotics: The WHO priority list of antibiotic-resistant bacteria and tuberculosis. Lancet. Infect. Dis. 2018, 18, 318-327. [CrossRef]

290. De Oliveira, D.M.P.; Forde, B.M.; Kidd, T.J.; Harris, P.N.A.; Schembri, M.A.; Beatson, S.A.; Paterson, D.L.; Walker, M.J. Antimicrobial resistance in ESKAPE pathogens. Clin. Microbiol. Rev. 2020, 33, e00181-19. [CrossRef]

291. Woolhouse, M.; Waugh, C.; Perry, M.R.; Nair, H. Global disease burden due to antibiotic resistance state of the evidence. J. Glob. Health 2016, 6, 10306. [CrossRef] [PubMed]

292. Pang, Z.; Raudonis, R.; Glick, B.R.; Lin, T.-J.; Cheng, Z. Antibiotic resistance in Pseudomonas aeruginosa: Mechanisms and alternative therapeutic strategies. Biotechnol. Adv. 2019, 37, 177-192. [CrossRef] [PubMed]

293. Chen, W.; Dong, B.; Liu, W.; Liu, Z. Recent advances in peptide nucleic acids as antibacterial agents. Curr. Med. Chem. 2021, 28, 1104-1125. [CrossRef]

294. Kole, R.; Krainer, A.R.; Altman, S. RNA therapeutics: Beyond RNA interference and antisense oligonucleotides. Nat. Rev. Drug Discov. 2012, 11, 125-140. [CrossRef]

295. Pifer, R.; Greenberg, D.E. Antisense antibacterial compounds. Transl. Res. 2020, 223, 89-106. [CrossRef]

296. Vogel, J. An RNA biology perspective on species-specific programmable RNA antibiotics. Mol. Microbiol. 2020, 113, 550-559. [CrossRef]

297. Good, L.; Nielsen, P.E. Antisense inhibition of gene expression in bacteria by PNA targeted to mRNA. Nat. Biotechnol. 1998, 16, 355-358. [CrossRef] [PubMed]

298. Forster, A.C.; Altman, S. External guide sequences for an RNA enzyme. Science 1990, 249, 783-786. [CrossRef]

299. Wojciechowska, M.; Równicki, M.; Mieczkowski, A.; Miszkiewicz, J.; Trylska, J. Antibacterial peptide nucleic acids-facts and perspectives. Molecules 2020, 25, 559. [CrossRef]

300. Castillo, J.I.; Równicki, M.; Wojciechowska, M.; Trylska, J. Antimicrobial synergy between mRNA targeted peptide nucleic acid and antibiotics in E. coli. Bioorg. Med. Chem. Lett. 2018, 28, 3094-3098. [CrossRef]

301. Martínez-Guitián, M.; Vázquez-Ucha, J.C.; Álvarez-Fraga, L.; Conde-Pérez, K.; Bou, G.; Poza, M.; Beceiro, A. Antisense inhibition of $l p x B$ gene expression in Acinetobacter baumannii by peptide-PNA conjugates and synergy with colistin. J. Antimicrob. Chemother. 2020, 75, 51-59. [CrossRef]

302. Ayhan, D.H.; Tamer, Y.T.; Akbar, M.; Bailey, S.M.; Wong, M.; Daly, S.M.; Greenberg, D.E.; Toprak, E. Sequence-specific targeting of bacterial resistance genes increases antibiotic efficacy. PLoS Biol. 2016, 14, e1002552. [CrossRef]

303. Howard, J.J.; Sturge, C.R.; Moustafa, D.A.; Daly, S.M.; Marshall-Batty, K.R.; Felder, C.F.; Zamora, D.; Yabe-Gill, M.; Labandeira-Rey, M.; Bailey, S.M.; et al. Inhibition of Pseudomonas aeruginosa by peptide-conjugated phosphorodiamidate morpholino oligomers. Antimicrob. Agents Chemother. 2017, 61, e01938-16. [CrossRef] [PubMed] 
304. Ghosal, A.; Nielsen, P.E. Potent antibacterial antisense peptide-peptide nucleic acid conjugates against Pseudomonas aeruginosa. Nucleic Acid Ther. 2012, 22, 323-334. [CrossRef]

305. Aunins, T.R.; Erickson, K.E.; Chatterjee, A. Transcriptome-based design of antisense inhibitors potentiates carbapenem efficacy in CRE Escherichia coli. Proc. Natl. Acad. Sci. USA 2020, 117, 30699-30709. [CrossRef]

306. Moustafa, D.A.; Wu, A.W.; Zamora, D.; Daly, S.M.; Sturge, C.R.; Pybus, C.; Geller, B.L.; Goldberg, J.B.; Greenberg, D.E. Peptideconjugated phosphorodiamidate morpholino oligomers retain activity against multidrug-resistant Pseudomonas aeruginosa in vitro and in vivo. MBio 2021, 12, e02411-20. [CrossRef] [PubMed]

307. Mondhe, M.; Chessher, A.; Goh, S.; Good, L.; Stach, J.E.M. Species-selective killing of bacteria by antimicrobial peptide-PNAs. PLoS ONE 2014, 9, e89082. [CrossRef] [PubMed]

308. Otsuka, T.; Brauer, A.L.; Kirkham, C.; Sully, E.K.; Pettigrew, M.M.; Kong, Y.; Geller, B.L.; Murphy, T.F. Antimicrobial activity of antisense peptide-peptide nucleic acid conjugates against non-typeable Haemophilus influenzae in planktonic and biofilm forms. J. Antimicrob. Chemother. 2017, 72, 137-144. [CrossRef]

309. Melamed, S.; Adams, P.P.; Zhang, A.; Zhang, H.; Storz, G. RNA-RNA Interactomes of ProQ and Hfq reveal overlapping and competing roles. Mol. Cell 2020, 77, 411-425. [CrossRef]

310. Immer, C.; Hacker, C.; Wöhnert, J. Solution structure and RNA-binding of a minimal ProQ-homolog from Legionella pneumophila (Lpp1663). RNA 2020, 26, 2031-2043. [CrossRef] [PubMed]

311. Holmqvist, E.; Berggren, S.; Rizvanovic, A. RNA-binding activity and regulatory functions of the emerging sRNA-binding protein ProQ. Biochim. Biophys. Acta Gene Regul. Mech. 2020, 1863, 194596. [CrossRef]

312. Stein, E.M.; Kwiatkowska, J.; Basczok, M.M.; Gravel, C.M.; Berry, K.E.; Olejniczak, M. Determinants of RNA recognition by the FinO domain of the Escherichia coli ProQ protein. Nucleic Acids Res. 2020, 48, 7502-7519. [CrossRef]

313. Bauriedl, S.; Gerovac, M.; Heidrich, N.; Bischler, T.; Barquist, L.; Vogel, J.; Schoen, C. The minimal meningococcal ProQ protein has an intrinsic capacity for structure-based global RNA recognition. Nat. Commun. 2020, 11, 2823. [CrossRef]

314. Pandey, S.; Gravel, C.M.; Stockert, O.M.; Wang, C.D.; Hegner, C.L.; LeBlanc, H.; Berry, K.E. Genetic identification of the functional surface for RNA binding by Escherichia coli ProQ. Nucleic Acids Res. 2020, 48, 4507-4520. [CrossRef] [PubMed]

315. Müller, P.; Gimpel, M.; Wildenhain, T.; Brantl, S. A new role for CsrA: Promotion of complex formation between an sRNA and its mRNA target in Bacillus subtilis. RNA Biol. 2019, 16, 972-987. [CrossRef] [PubMed]

316. Ul Haq, I.; Müller, P.; Brantl, S. Intermolecular communication in Bacillus subtilis: RNA-RNA, RNA-protein andsmall proteinprotein interactions. Front. Mol. Biosci. 2020, 7, 178. [CrossRef] [PubMed] 